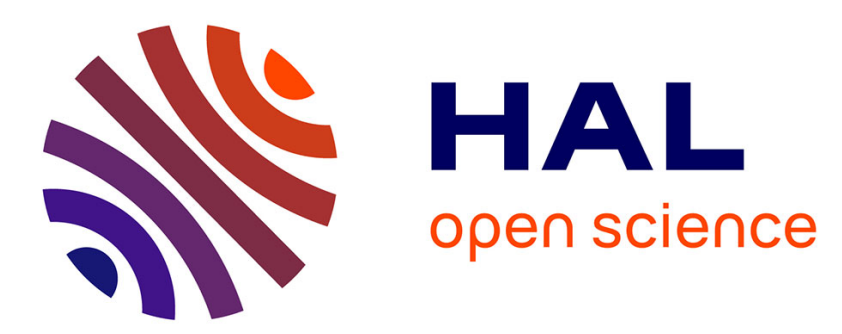

\title{
A generic model for the shallow velocity structure of volcanoes
}

\author{
Philippe Lesage, Michael Heap, Alexandra Kushnir
}

\section{To cite this version:}

Philippe Lesage, Michael Heap, Alexandra Kushnir. A generic model for the shallow velocity structure of volcanoes. Journal of Volcanology and Geothermal Research, In press, 10.1016/j.jvolgeores.2018.03.003 . hal-01726063

\section{HAL Id: hal-01726063 \\ https://hal.science/hal-01726063}

Submitted on 7 Mar 2018

HAL is a multi-disciplinary open access archive for the deposit and dissemination of scientific research documents, whether they are published or not. The documents may come from teaching and research institutions in France or abroad, or from public or private research centers.
L'archive ouverte pluridisciplinaire HAL, est destinée au dépôt et à la diffusion de documents scientifiques de niveau recherche, publiés ou non, émanant des établissements d'enseignement et de recherche français ou étrangers, des laboratoires publics ou privés. 


\title{
A generic model for the shallow velocity structure of volcanoes
}

\author{
Philippe Lesage ${ }^{1, *}$, Michael J. Heap ${ }^{2}$, Alexandra Kushnir ${ }^{2}$ \\ ${ }^{1}$ ISTerre, Université Savoie Mont-Blanc, Université Grenoble Alpes, CNRS, IRD, IFSTTAR, 38000 \\ Grenoble, France \\ ${ }^{2}$ Géophysique Expérimentale, Institut de Physique de Globe de Strasbourg (UMR 7516 CNRS, \\ Université de Strasbourg/EOST), 5 rue René Descartes, 67084 Strasbourg, France \\ * Corresponding author, lesage@univ-smb.fr, Université Savoie Mont-Blanc, ISTerre, Campus \\ scientifique, 73376 Le Bourget-du-Lac cedex, France
}

\begin{abstract}
The knowledge of the structure of volcanoes and of the physical properties of volcanic rocks is of paramount importance to the understanding of volcanic processes and the interpretation of monitoring observations. However, the determination of these structures by geophysical methods suffers limitations including a lack of resolution and poor precision. Laboratory experiments provide complementary information on the physical properties of volcanic materials and their behavior as a function of several parameters including pressure and temperature. Nevertheless combined studies and comparisons of field-based geophysical and laboratory-based physical approaches remain scant in the literature. Here, we present a meta-analysis which compares 44 seismic velocity models of the shallow structure of eleven volcanoes, laboratory velocity measurements on about one hundred rock samples from five volcanoes, and seismic well-logs from deep boreholes at two volcanoes. The comparison of these measurements confirms the strong variability of $\mathrm{P}$ - and S-wave velocities, which reflects the diversity of volcanic materials. The values obtained from laboratory experiments are systematically larger than those provided by seismic models. This discrepancy mainly results from scaling problems due to the difference between the sampled volumes. The averages of the seismic models are characterized by very low velocities at the surface and a strong velocity increase at shallow depth. By adjusting analytical functions to these averages, we define a generic model that can describe the variations in $\mathrm{P}$ - and S-wave velocities in the first $500 \mathrm{~m}$ of andesitic and basaltic volcanoes. This model can be used for volcanoes where no structural information is available. The model can also account for site time correction in hypocenter determination as well as for site and path effects that are commonly observed in volcanic structures.
\end{abstract}

Keywords: Seismic experiments; ultrasonic measurements; seismic well-logging; volcano structure; velocity model; petrophysics

\section{Introduction}


Volcanoes are complex structures made of materials that present strong heterogeneity at lengthscales from micrometers to kilometers (e.g. Manconi et al., 2007; Farquharson et al., 2016). Volcanic edifices result from the variable (in time and space) accumulation of successive effusive and explosive eruptions and endogenous growth (e.g. Borgia and Linneman, 1990; Kaneko et al., 2002; Biggs et al., 2010; Odbert et al., 2015). The structure of the edifices and the mechanical properties of their materials play a major role in the response of a particular volcano to, for example, magma intrusion and recharge (e.g. ground deformation and, possibly, eruption style) (e.g. Manconi et al., 2007; Hautmann et al., 2010; Geyer and Gottsmann, 2010; Heap et al., 2015a). The depth and volume of the storage zones determine the petrological evolution and eruptability of magma (e.g. Gardner et al., 1995; Devine et al., 1998; Barclay et al., 1998; Martel et al., 1998). The knowledge of these parameters is important in the interpretation of petrological analyses and the construction of eruption models. The porosity and permeability of rocks and rock masses control the outgassing of the magma column, especially at shallow depth, which contributes to the eruptive style - effusive or explosive - of the volcanic activity (e.g. Eichelberger et al., 1986; Saar and Manga, 1999; Rust and Cashman, 2004; Rust et al., 2004; Mueller et al., 2005; Lavallée et al., 2013; Gaunt et al., 2014; Heap et al., 2015b; Kushnir et al., 2017a; Farquharson et al., 2017a). Furthermore, the stability of the edifice depends greatly on the material strength and possible structural weakness (Voight, 2000; Thomas et al., 2004; Apuani et al., 2005; Heap et al., 2015a; Cook et al., 2017). The knowledge of the internal structure of volcanoes is also of paramount importance in the interpretation of observations made by monitoring networks, building interpretative models, and designing simulations of deformation or wave propagation. In particular, good velocity models are key elements for obtaining precise hypocenter locations in order to detect magma migration or for identifying active faults (e.g. Chiarabba et al., 2000; Lengliné et al., 2016).

However, the determination of the structure of volcanoes is a difficult and challenging problem. Many methods have been developed and used to obtain seismic velocity models of volcanic structures, either in 1-D or in 3-D (Chouet, 1996): body wave travel-time tomography, surface wave tomography, array analysis, and the minimization of residuals in source location (e.g. Jolly et al., 1994). The data used in these studies are obtained by either active or passive field experiments. Nevertheless, all these seismic methods suffer some limitation in resolution, precision, penetration depth, and/or sampling of the structures. This is due to insufficient instrumental or source coverage, the use of wavelengths that are too long to properly resolve volcanic structures, or strong attenuation and the scattering of the seismic waves in these structures. Although new experiments are carried out every year at some volcanoes, the number of velocity models of volcanic structures is still limited. As a result, the structure of most volcanoes in the world is poorly or even completely unconstrained and, in many cases, modelling and the determination of hypocenter locations must use homogeneous and/or empirical velocity models, which strongly reduce the precision of the calculations.

Well-constrained laboratory experiments have provided useful information on the physical properties of volcanic rocks. These experiments generally involve measuring rock properties - including ultrasonic P- and S-wave velocity (e.g. Vanorio et al., 2002; Vinciguerra et al., 2005; Scheu et al., 2006; Heap et al., 2014a; 2014b; Nara et al., 2011; Fortin et al., 2011), density, porosity, and permeability (e.g. Vinciguerra et al., 2005; Nara et al., 2011; Fortin et al., 2011; Farquharson et al., 2015; Heap and Kennedy, 2016; Kushnir et al., 2016) - on geometrically well-constrained samples. In many cases, a confining pressure or an axial stress (or both) is applied to the samples, which allows these physical properties to be studied as a function of equivalent depth. The influence of temperature (e.g. Scheu 
et al., 2006; Gaunt et al., 2016; Tripoli et al., 2016; Kushnir et al., 2017b), water saturation (e.g. Vinciguerra et al., 2006; Fortin et al., 2011; Adam and Otheim, 2013; Heap et al., 2014b), alteration (e.g. Wyering et al., 2014; Heap et al., 2017a), and material damage (e.g. Nara et al., 2011; Fortin et al., 2011) have also been studied in these types of laboratory investigations. Elastic wave velocity data has also been used to infer crack damage and crack density (e.g. Harnett et al., 2018).

A third source of information comes from boreholes in volcanic structures. Indeed, in a small number of active volcanoes, boreholes have been drilled up to a few hundred or thousand meters into the volcano and in situ measurements of physical properties of volcanic materials have been obtained through well-logging (e.g. Ikeda et al., 2008; Mariucci et al., 2008). In other cases, core samples have been extracted from the boreholes at various depths and physical parameters were measured directly on the samples in the laboratory (e.g. Zamora et al., 1994; Siratovich et al., 2014).

This paper presents the results of a meta-analysis of published velocity models and direct measurements obtained from laboratory experiments and well-logging. This work is thus based on a (non-exhaustive) compilation of papers in volcano seismology and rock mechanics. Its objectives are 1) to study the consistency of seismic velocity profiles obtained using different approaches, 2) to investigate possible general trends for the variations of seismic velocities with depth and 3 ) to produce generic velocity models that could be used at volcanoes where the level of information on the structure is almost zero. Part of the study is focused on the shallow $(<1000 \mathrm{~m})$ layers of volcanic structures. These layers are generally unresolved in tomographic studies because of poor ray coverage or because of the large wavelength of surface waves. However, at shallow depth, the poorly consolidated materials are characterized by very low velocities and strong gradients that produce large propagation effects such as wave trapping, marked site effects, and a delay in the arrival times of body waves. By averaging many velocity models from various volcanoes, we propose a generic 1-D P-wave $\left(V_{P}\right)$ and Swave $\left(V_{s}\right)$ model for the first $500 \mathrm{~m}$ below the surface, which could be used to build reference models for tomographic studies or to improve source location where no velocity models are available.

\section{Data}

The data analyzed here were extracted from published papers. In some cases, they were processed in order to present all the velocities as a function of depth below the free surface. We also provide new laboratory data for andesites and basaltic-andesites. Volcanoes are classified in this study as either andesitic, basaltic or caldera so that these different broad classes of volcano can be investigated separately. In the following, dacitic and andesitic volcanoes are considered together.

\subsection{Velocity models}

Several methods are used by seismologists to obtain velocity models of volcanic structures. The resolution and depth of investigation of the resulting models depend on the methods used, on the type and wavelength of the seismic waves analyzed, on the geometry of the seismic network, on the distribution of the sources, and on the volume of data processed. The travel-time tomography is based on the inversion of arrival times of body-waves from passive or active sources (Chouet, 1996; DíazMoreno et al., 2017). Tomographic inversions provide meaningful estimates of seismic velocity only for those regions of the model space which are crossed by a sufficient number of ray segments with different orientations. This condition is rarely fulfilled below seismic stations because most of the rays 
close to the free surface propagate almost vertically. The models are thus poorly constrained below the stations and are not defined at all between stations at shallow depth. Their resolution depends on the number and distribution of stations and seismic sources. The analysis of surface waves is based on the measurement of phase and group velocities of Rayleigh or Love waves as a function of frequency (Barmin et al., 2001). The obtained dispersion curves can be inverted to estimate 1-D velocity models that are representative of the average structure along the wave path. Alternatively, the group and phase velocities can be regionalized at each frequency in order to reconstruct dispersion curves for each cell of the surface. In the next step of the procedure, these curves are inverted to estimate a 1-D velocity model at each point. Together, these models form 3-D images of the structure. The ambient noise cross-correlation method retrieves the Green functions of surface waves between any pairs of receivers. This approach is now widely used to carry out surface wave tomography (e.g. Zulfakriza et al., 2014; Mordret et al., 2015; Spica et al., 2016).

The spatial autocorrelation (SPAC) (Aki, 1957) and the frequency-wavenumber (f-k) (Capon, 1969) methods are based on the analysis of seismic noise recorded by small dense arrays. They provide dispersion curves that can be inverted for local 1-D velocity structures at depths of a few hundreds of meters. Because these methods are relatively easy to carry out in the field, they have been applied at many sites around some volcanoes (Métaxian et al., 1997; Saccorotti et al., 2003; 2004; Mora et al., 2006; Perrier et al., 2012). The horizontal to vertical spectral ratio (HVSR) is mainly used to study site effects. However, recent theoretical developments (Sánchez-Sesma et al., 2011) have showed that 1D velocity models can be retrieved from the inversion of the HVSR. This approach was used by Spica et al. (2015) to investigate the structure of Kawah ljen volcano in Indonesia. For many volcanoes, no structural studies have been undertaken and very simple velocity models are used for hypocenter locations. These models, which consist of one layer or a few homogeneous layers, have often been obtained by minimizing the residuals of arrival times during the determination of hypocenters. They are also used as reference models for local tomography (Kissling et al., 1994). Finally, in some cases, 1D velocity models have been constrained using data from controlled chemical explosions (Lahr et al., 1994; Thelen et al., 2008).

The velocity models that can be found in the literature are presented either in tables, as curves, or as images with grey or color scales. In the present work, we analyze only 1-D models extracted by copying tables or by digitizing curves (Table 1). The origin of depth is set at the free surface and the models are interpolated every ten meters. Then, all the models corresponding to a given volcano are averaged at each depth with the condition that at least two values are available. Finally, the mean models of all volcanoes are averaged again. Models estimated by SPAC, f-k, HSVR and local surface wave analysis are characterized by high vertical resolution, but they do not extend much more than $500 \mathrm{~m}$ deep. On the other hand, models obtained from large-scale experiments (McNutt and Jacob, 1986), or by minimization of arrival time residuals (Jolly et al., 1994), image the whole crust but generally have extremely limited resolution in the first few kilometers. These two categories of model (Dixon et al., 2010) are not considered in the present study.

\subsection{Measurements of rock physical properties}

Elastic waves velocities can be measured directly in laboratory petrophysical experiments using ultrasonic pulse-transmission techniques (Birch, 1960). These studies are frequently carried out 
together with porosity and permeability measurements. Cylindrical or parallelipipedic samples (typically between 10 and $125 \mathrm{~cm}^{3}$ ) are prepared from blocks of rock collected in the field. Laboratory samples are often prepared to avoid discontinuities and obvious variations in texture or appearance. Two or more piezoelectric transducers are coupled to the samples in order to measure $V_{p}, V_{S}$, and, sometimes, SV- and SH-wave velocities. One of the transducers is excited by a pulse generator and the elastic waves are detected by the remaining transducer(s) after propagating through the sample. Velocities are calculated from the travel-times and the dimensions of the sample with a precision of a few percent. Further, these piezoelectric transducers are sometimes used to detect acoustic emissions produced by crack propagation associated with inelastic deformation during deformation experiments (e.g. Stanchits et al., 2006; Fortin et al., 2011). Very recently, the first arrivals from acoustic emissions during a laboratory deformation experiment have been used to construct $\mathrm{P}$-wave velocity heat maps of the deforming sample (Brantut, 2018).

$V_{P}$ and $V_{S}$ depend on the physical attributes of volcanic rock (particularly porosity) and are strongly modified by various factors such as water saturation, temperature and confining pressure. Thus, many published studies have compared velocity measurements on dry and saturated samples (e.g. Zamora et al., 1994), the velocity variations as a function of temperature (e.g. Scheu et al., 2006), and the influence of confining pressure (e.g. Vinciguerra et al., 2005; Nara et al., 2011).

In the present work, we have extracted velocity measurements from several studies that report velocity as a function of either the confining pressure $P_{c}$ or the effective pressure $P_{e}=P_{c}-P_{p}$, where $P_{p}$ is the pore fluid pressure. In some experiments on saturated samples, the pore pressure used can be up to $10 \mathrm{MPa}$ (Vinciguerra et al., 2005; 2006; Kolzenburg et al., 2012). We used the values of sample density, $\rho$, found in the papers to calculate the corresponding depth, $z$, using the lithostatic approximation: $z=P / \rho g$. We note that the assumption of constant density likely introduces some bias in the values of depth. Indeed, due to the presence of poorly consolidated material, the averaged density in the shallow layers is lower than those measured on rock samples in the laboratory and the corresponding density profile is characterized by a marked gradient. Using lower values of density in the shallow layers yields larger calculated depths for a given pressure and thus smaller velocity gradients than those estimated using our approximation.

A large variety of volcanic rocks has been characterized in laboratory studies: tuff from Campi Flegrei (Italy) (Zamora et al., 1994; Vanorio et al., 2002; Vinciguerra et al., 2006; Heap et al., 2014b), basalt from Mt. Etna (Italy) (Vanorio et al., 2002; Vinciguerra et al., 2005; Stanchits et al., 2006; Fortin et al., 2011), andesite from Volcán de Colima (Mexico) (Kolzenburg et al., 2012; Heap et al., 2014a) and dacite from Unzen volcano (Japan) (Scheu et al., 2006). We complement these data with unpublished data on andesite from Volcán de Colima and andesite and basaltic-andesite from Merapi (Indonesia). A total of 140 individual cylindrical samples (20 mm in diameter and nominally $40 \mathrm{~mm}$ in length) were measured for this study: 25 from Merapi and 115 from Volcán de Colima (Table 2). These measurements were performed at the Université de Strasbourg using a device that couples a digital oscilloscope (Agilent Technologies DS05012A digital storage oscilloscope), a waveform pulse generator (Agilent Technologies 33210A, $10 \mathrm{MHz}$ function/waveform generator), and two piezoelectric transducers (see Heap et al., 2014a). The samples were first dried in a vacuum at $40{ }^{\circ} \mathrm{C}$ for a minimum of $48 \mathrm{~h}$. A constant stress (about $1 \mathrm{MPa}$ ) was applied to the samples during the measurements to ensure good signal transmission. The frequency of the generated signal was set at 700 and $300 \mathrm{kHz}$ for 
$\mathrm{P}$-waves and S-waves, respectively. These measurements were performed at ambient pressure and temperature.

\subsection{Well-logging}

The most direct way of obtaining information on volcanic structures and rock properties is to drill deep boreholes. However, except for geothermal purposes, very few deep drilling campaigns have been carried out for scientific interest worldwide (see http://www.icdp-online.org). When core samples have been available, their physical properties and mineral contents have been determined in the laboratory (e.g. Eichelberger et al., 1988; Zamora et al., 1994; Vinciguerra et al., 2009). In some cases, geophysical well-logging allowed in situ measurements of rock characteristics (Sakuma et al., 2008; Ikeda et al., 2008; Mariucci et al., 2008; Vinciguerra et al., 2009). For the purpose of the present review, we use well-logging data from Alban Hills volcanic complex (Italy) (Mariucci et al., 2008; Vinciguerra et al., 2009) and Unzen volcano (Sakuma et al., 2008; Ikeda et al., 2008).

In the framework of the Unzen Scientific Drilling Project (USDP), a $1800 \mathrm{~m}$ long borehole (USDP-4) was drilled in 2003 at a site located at $840 \mathrm{~m}$ a.s.l. and $1000 \mathrm{~m}$ north of the summit (Nakada et al., 2005). Drilling started vertically and was then deviated at an angle of $70^{\circ}$ from vertical in order to penetrate the magma conduit that fed the 1991-1995 eruption. In parts of these boreholes, well-logs were collected to determine density, P-wave and S-wave velocity, and porosity, amongst other properties. We retrieved the log data from Ikeda et al. (2008) and we used the topographic profile of Unzen volcano over borehole USDP-4 to calculate the ground thickness over each point logged. We then obtained the measured $\mathrm{P}$ - and $\mathrm{S}$-wave velocities as a function of depth below the corresponding point of the free surface. At USDP-4, measurements were carried out in the ranges of 400-650 and 800-1800 $\mathrm{m}$ along the borehole, which corresponds to depth intervals of 450-830 and 1020-1500 m, respectively, below the free surface. S-wave velocity was obtained only on the shallowest depth range (450-830 m), but we note that measurements in this range were of poor quality.

A 350 m deep scientific borehole was drilled in the western sector of the Alban Hills volcanic complex. In this borehole, well-logging, including P-wave velocity measurements, was carried out down to a depth of $100 \mathrm{~m}$ (Vinciguerra et al., 2009). Using tuff samples from borehole cores, P- and S-wave velocities were also measured at effective pressures between 5 and $70 \mathrm{MPa}$ (Vinciguerra et al., 2009). These authors found that the rate of velocity variation with pressure strongly depended on the stratigraphic unit from which the samples were extracted. $V_{p}$ and $V_{S}$ increased by 3 to $17 \%$ and by 2 to $16 \%$, respectively, when pressure was increased from 5 to $70 \mathrm{MPa}$. It was found that the magnitude of the increase depended on the initial physical properties of the tuff (Vinciguerra et al., 2009). Importantly, the P-wave velocities measured in the laboratory and obtained from well-logging were found to be consistent (Vinciguerra et al., 2009).

\section{Results}

All the data gathered for the present analysis are displayed in a series of figures with different depth scales. $V_{P}$ and $V_{S}$ are presented separately, as well as $V_{P} / V_{S}$ when this ratio could be calculated. Figure 1 displays all the individual models and measurements obtained for andesitic and basaltic volcanoes in the depth range $0-1500 \mathrm{~m}$, as well as the averaged seismic models calculated for each volcano and the average of the averaged models. The enlargements of these individual models for the first $500 \mathrm{~m}$ 
highlight the variability at that depth interval (Figure 2). Figure 3 presents the averaged models and measurements for depths up to $4000 \mathrm{~m}$ for andesitic and basaltic volcanoes. Figure 4 displays single seismic models and well-log and laboratory measurements in the first $4000 \mathrm{~m}$ for the volcanoes classified as calderas. Figure 5 is a close up of $V_{s}$ that includes averaged models for depths less than $1000 \mathrm{~m}$ for the calderas.

The main feature that appears when displaying the set of velocity values is their significant and pervasive variability. This remains true when comparing velocity models obtained at different sites within a single volcano (see e.g. Mt. Yasur (Vanuatu) and Ischia island (Italy)), as well as between the averages of the velocity profiles calculated for each volcano. The variability is even larger for the velocities measured on samples in laboratory experiments (see discussion in section 4). The velocity profiles measured by well-logging at Unzen volcano and Alban Hills also show a strong variability as a function of depth. Variations of $\pm 800 \mathrm{~ms}^{-1}$ or more are observed over a few tens of meters along the profiles. These rates of variation are much larger than the mean velocity gradient $\left(\sim 0.7 \mathrm{~ms}^{-1}\right.$ per meter for $V_{p}$ over a depth range of $1000 \mathrm{~m}$ at Unzen volcano).

In the first $500 \mathrm{~m}$, no clear differences can be detected in the averaged velocity models between the basaltic, andesitic and dacitic volcanoes (Figure 2). All these models are characterized by marked velocity gradient close to the surface, which progressively decreases as a function of depth. In the case of calderas (Figures 4 and 5 ), the gradient of the averaged S-wave velocity model is almost constant in the first $1000 \mathrm{~m}$ (with a value of $\sim 1.5 \mathrm{~ms}^{-1}$ per meter; Figure 5). Unfortunately, there are currently not enough $V_{p}$ models for calderas to be included in this comparison. When the methods used to estimate the velocity models have good sensitivity at very shallow depth (SPAC, $\mathrm{f}-\mathrm{k}$, surface wave analysis), the resulting values of $V_{P}$ and $V_{S}$ are very small close to the surface $\left(<500 \mathrm{~ms}^{-1}\right)$. With other methods, the parameters in this thin layer are not resolved.

The velocity profiles obtained through well-logging at Unzen volcano are consistent with the averaged velocity models (Figures 1 and 3). Overall, P-wave velocities observed in seismic logs increase with depth. However, the values measured in laboratory experiments are systematically larger than those obtained by seismic methods, especially in the shallowest layers. Furthermore, at shallow depth the velocity gradients estimated by laboratory experiments are generally much smaller than those associated with seismic models. The P-wave velocities measured in laboratories span an interval of $4600 \mathrm{~ms}^{-1}$ (from 1200 to $5800 \mathrm{~ms}^{-1}$ ) close to the surface (Figure 1a). This interval of variability decreases to $2000 \mathrm{~ms}^{-1}$ at a depth of $2000 \mathrm{~m}^{2}$ and to $1500 \mathrm{~ms}^{-1}$ at $4000 \mathrm{~m}$ (Figure 1a). For S-waves velocities, the widths of the corresponding intervals are 2200,1300 and $1200 \mathrm{~ms}^{-1}$, respectively (Figures $1 \mathrm{~b}$ ). A similar decrease of the variability with depth is observed for caldera material, although it is less pronounced (Figure 4). The velocity data unique to this study (measured on samples from Merapi and Volcán de Colima) are also shown in Figures 1 and 3 and displayed in Table 2. For the Merapi samples, the mean values and standard deviations are, respectively, 2518 and $595 \mathrm{~ms}^{-1}$ for $V_{p}$ and 1346 and $328 \mathrm{~ms}^{-1}$ for $\mathrm{V}_{\mathrm{s}}$. The corresponding $\mathrm{V}_{\mathrm{P}} / \mathrm{V}_{\mathrm{S}}$ ratio is 1.87 . For the Volcán de Colima samples, the mean P-wave velocity is $2610 \pm 180 \mathrm{~ms}^{-1}$.

When both $V_{P}$ and $V_{S}$ are available in any set of data, we calculated $V_{P} / V_{S}$. The variability of this ratio is also very pronounced for the seismic velocity models, as well as for laboratory measurements; this is a consequence of the wide range of velocity values (Figures $1 c, 3 c$, and $4 c$ ). The ratio of averaged compressional and shear waves velocity models is relatively constant in the first $500 \mathrm{~m}$, with $\mathrm{V}_{\mathrm{p}} / \mathrm{V}_{\mathrm{s}}=$ $1.96 \pm 0.09$ for andesitic and basaltic volcanoes. 


\section{Discussion}

Numerous studies have suggested ways of interpreting and explaining the characteristics of seismic velocities measured in laboratory or estimated from seismic experiments (e.g. Nur, 1971; Zimmerman et al., 1986; Vanorio et al., 2002). At a given condition of pressure and temperature, the seismic velocities of a volcanic rock depend on a number of parameters. Elastic wave velocities of volcanic rocks are not only dependent on their mineral content, but are also strongly dependent on the porosity and the nature of the porosity (microcrack density, pore number density, and pore size and shape, amongst others), which are a direct result of rock formation, emplacement, and transport. The large diversity of composition and microstructure of volcanic rocks (e.g. Shea et al., 2010; Heap et al., 2014a; Farquharson et al., 2015; Colombier et al., 2017) can thus explain the strong variability observed in their seismic velocities. The seismic velocity of volcanic rocks can also be modified post-emplacement. For example, thermal stressing due to rapid temperature variations can significantly increase the density of microcracks and reduce seismic velocities (e.g. Vinciguerra et al., 2005; 2006; Heap et al., 2014a). The P-wave velocity of volcanic rock can be reduced by hydrothermal alteration (e.g. Pola et al., 2012) and increased by mineral precipitation (Adam et al., 2013). The level of water saturation also has a marked effect on the P-wave velocity of rocks, and therefore on their $V_{P} / V_{S}$ ratio. The P-wave velocities of saturated volcanic rocks have been found to be larger than for dry volcanic rocks, due to the higher P-wave velocity of liquid compared to air (e.g. Zamora et al., 1994). Experiments have also shown that the velocity of a basalt was sensitive to the pore fluid chemistry: the wave velocity decreased by about $10 \%$ when water was replaced by liquid $\mathrm{CO}_{2}$ (Adam and Otheim, 2013).

Importantly, the P- and S-wave velocities of volcanic rocks are seen to increase under increasing effective pressure (e.g. Vinciguerra et al., 2005; Nara et al., 2011). Under upper crustal conditions, this is interpreted as the result of the closing of compliant microcracks (Mavko et al., 1995; Vinciguerra et al., 2005; Nara et al., 2011). In the case of saturated rock, increases in pore pressure will reduce the effective pressure acting on the rock, allowing microcracks to open thus decreasing the velocity (Vanorio et al., 2002). Under differential stress below the onset of inelastic damage, microcracks normal to the axis of the principal stress will close, while those that are parallel to the axis will be propped open (Lockner et al., 1977; Heap et al., 2014a). This can result in a faster elastic wave velocity parallel to the sample axis and a slower velocity perpendicular to the sample axis - thus, an anisotropy develops. Seismic anisotropies can also develop as a result of the preferential alignment of newly formed microcracks (parallel to the maximum principal stress) during the inelastic deformation of rock in the brittle field (e.g. Fortin et al., 2011).

We note that the velocities measured in laboratory are almost always systematically larger than those resulting from seismological models (Figures 1, 3 and 4). This may be partly due to the phenomenon of dispersion, i.e. the dependency of seismic velocities on measurement frequency. Dispersion is related to fluid flow mechanisms in pores and cracks (Schubnel and Guéguen, 2003) and to the effects of scattering on elastic waves by heterogeneities (Winkler, 1983). Laboratory measurements are made at ultrasonic frequency $(0.1$ to $1 \mathrm{MHz})$, while the seismic waves recorded in the field and used to calculate models have dominant frequencies on the order of 1 to $10 \mathrm{~Hz}$. For dry rocks, the effects of dispersion are small (Winkler, 1983). In saturated rocks, these effects are larger but do not exceed 1 to $10 \%$, especially at effective pressure of a few tens of MPa, and they decrease at higher pressure (Winkler, 1986; Zamora et al., 1994; Vinciguerra et al., 2006). Hence, the slight increases of velocity with frequency associated with dispersion cannot account for the large 
differences observed between the ultrasonic and the seismic measurements. On the other hand, due to the experimental conditions of the laboratory and field approaches - namely the large difference in wavelengths used to interrogate the material - the volumes of rock mass investigated differ by several orders of magnitude. Moreover, the rock samples are typically chosen to be as homogeneous as possible so as not to contain macroscopic fractures. To date, and to the knowledge of the authors, no laboratory measurements have been carried out on unconsolidated volcanic materials such as pyroclastic and lahar deposits. However, in practice, seismic waves propagate long distances through a medium that contains not only competent rock, but also large fractures and poorly consolidated material. The seismic velocities estimated from the analysis of these waves thus represent averaged values over large volumes. These values are smaller than those measured on competent and homogeneous samples and, thus, the latter ones should be considered as upper bounds of the velocity in a given volcano.

The best description of real volcanic structure at intermediate scale is probably given by seismic welllogs. Thanks to the short wavelengths used (a few tens of $\mathrm{cm}$ ) and the high resolution provided by this type of in-situ measurement, detailed profiles of velocity can be obtained. These observations are able to resolve large seismic velocity variations on the scale of the thickness of the layers of material that comprises the edifice (Ikeda et al., 2008; Vinciguerra et al., 2009). This strong heterogeneity is probably present in the three dimensions of space and is related to the marked scattering behavior of seismic waves in the shallow part of volcanic structures (Wegler and Lühr, 2001). For a seismic wave with a wavelength much longer than the distance over which the properties of the material change significantly, the medium behaves like a nearly homogeneous body. Indeed, the density of this equivalent medium is the average density of the layers and its elastic coefficients are combinations of averaged algebraic combinations of elastic coefficients of the original layers (Backus, 1966). As an example, Vanorio et al. (2005) obtained a good agreement between a vertical velocity model extracted from a tomographic study of Campi Flegrei and a profile obtained by averaging well-log data. The seismological models that generally describe the structures as a small series of homogeneous layers or parallelepipedic cells are thus very simplified representations, although they are useful for source location or simulation of wave propagation. Thus, the velocity contrasts that appear between these theoretical layers probably do not reflect those in real volcanoes.

The increase in average velocity with depth is due to processes that can be studied by laboratory experiments. Under increasing lithostatic pressure, the most compliant macro- and microfractures and pores close first, followed by less compliant ones, and so on. This is consistent with the observation that the velocity gradient is strongest close to the surface and progressively decreases with depth. Less consolidated materials are more easily compacted under a lithostatic load than denser and more competent ones. As a consequence, not only does the variability of the velocity models and laboratory measurements reduce, but the difference between the velocity models and laboratory measurements is also decreased with increasing depth (Figures 1, 3 and 4). Furthermore, the material anisotropy decreases with depth and becomes more homogenous (Scheu et al., 2006). Consequently, the transport mean free path of the medium, which plays an important role in seismic attenuation by wave scattering and in the propagation of diffuse wavefields (e.g. Del Pezzo et al., 2001; Rossetto et al., 2011; Lesage et al., 2014), is probably an increasing function of depth although, to our knowledge, this dependency has never been studied in volcanic structures.

The $V_{P} / V_{S}$ ratio is related to the Poisson's ratio by the equation $V_{P} / V_{S}=2(1-v) /(1-2 v)$. These parameters are good indicators of the physical properties of the medium because they depend on 
composition, fluid content, pressure and temperature. Handbooks of rock properties indicate that for dry and intact (on the sample lengthscale) andesite and basalt at ambient pressure and temperature conditions, typical values of Poisson's ratio are from 0.1 to 0.35 (Gercek, 2007 and references therein). The corresponding values of $V_{P} / V_{s}$ therefore range between 1.5 and 2.1. For the velocity models and the measurements reported in the present study, we note that a few values are outside this interval (Figures 1c, 3c, 4c). This may indicate either error in estimating the P-and S-waves velocities or some departure from the velocities measured on dry samples under ambient conditions. In dry rocks, when temperature increases, the S-wave velocity decreases more rapidly than the P-wave velocity, due to the softening of the groundmass (Mizutani and Kanamori, 1964). Thus $V_{P} / V_{S}$ increases with temperature and the partial melting of the medium is associated with high ratios. In fluid-saturated rocks, $V_{P}$ is strongly influenced by the fluid compressibility. Therefore, liquid-bearing formations are characterized by high values of $V_{p} / V_{s}$ while gas-bearing formations have low $V_{p} / V_{s}$. Hence phase transitions in the fluid produce strong variations to the velocity ratio (Ito et al., 1979). On the other hand, an increase in the pore pressure can generate two competing effects: 1) a vapor to liquid phase transition that reduces fluid compressibility yields larger values of $V_{P} / V_{s}$; and 2) the opening of microcracks and an increase in porosity, which decreases the ratio (Vanorio et al., 2005 and references therein). Thus, it is necessary to systematically discuss any estimation of the velocities in terms of $V_{p} / V_{S}$ in the corresponding volcanological context. This type of discussion may help constrain seismic data inversion and define some reliability criteria on the resulting models or on the laboratory measurements. For example, the very low and very high values of $V_{p} / V_{S}$ obtained for some velocity models (Figure 3c) may indicate some inconsistency in the corresponding calculations. This could result from bias in the inversion of dispersion curves obtained from array analysis due to contamination by higher modes and to poor constrain on $V_{p}$.

\section{Generic model}

In the first $500 \mathrm{~m}$ below the surface, where the number of velocity models found in the literature is relatively high, the average $V_{p}$ and $V_{S}$ curves for all andesitic and basaltic volcanoes are quite smooth and show a progressive decrease in their gradients with depth (Figures 1 and 3). This observation suggests that analytical functions could correctly describe these average models. Thus, we fit power laws to the averaged $V_{P}$ and $V_{S}$ curves such as:

$$
V(z)=V_{0}\left\lfloor(z+a)^{\alpha}-a^{\alpha}+1\right]
$$

where $V_{0}$ is the velocity at the surface. For $\mathrm{z}<500 \mathrm{~m}$, we obtained the following parameters: $\left[V_{P O}=540 \mathrm{~m} \mathrm{~s}^{-1}, \alpha_{P}=0.315, a_{P}=10\right]$ and $\left[V_{S O}=320 \mathrm{~m} \mathrm{~s}^{-1}, \alpha_{S}=0.30, a_{S}=15\right]$ for P- and S-waves, respectively. Figure 6 shows good agreement between the average and the analytical curves. The corresponding misfit is defined as:

$$
\chi=\left\{\frac{1}{N} \sum_{i=1}^{N}\left[V_{\text {ave }}\left(z_{i}\right)-V_{\text {ana }}\left(z_{i}\right)\right]^{2}\right\}^{\frac{1}{2}}
$$

where $V_{\text {ave }}\left(z_{i}\right)$ and $V_{\text {ana }}\left(z_{i}\right)$ are, respectively, the averaged and the analytical values of the velocities obtained at $N$ depths $z_{i}$, is of the order of $100 \mathrm{~ms}^{-1}$ for both P- and S-wave velocities. 
Figure $6 c$ displays the $V_{P} / V_{S}$ ratio of the analytical models that have values close to 1.95 in the whole layer except in the first tens of meters. Following these models, $V_{p}$ increases from 540 to $3270 \mathrm{~m} \mathrm{~s}^{-1}$ and $V_{s}$ from 320 to $1680 \mathrm{~m} \mathrm{~s}^{-1}$ in this 500 m-thick layer. We suggest these analytical functions should be used as generic $V_{P}$ and $V_{S}$ models whenever no reliable information is available on the velocity structure of a volcano at shallow depth. Although the measured velocity values are highly variable, it is convenient to use the proposed models instead of assuming a homogeneous subsurface structure with a large, constant seismic velocity. The travel-time of a vertically propagating P-wave through the $500 \mathrm{~m}$-thick layer described by the generic model is $0.248 \mathrm{~s}$. For a homogeneous structure with $\mathrm{V}_{\mathrm{P}}=$ $4000 \mathrm{~m} \mathrm{~s}^{-1}$, the corresponding travel-time is $0.125 \mathrm{~s}$. Thus the difference between the two values may account for a site delay of $0.123 \mathrm{~s}$, an order of magnitude commonly used for site corrections in hypocenter determinations. As a consequence, the use of the generic model instead of a homogeneous structure may improve the accuracy of hypocenter determination at active volcanoes worldwide.

Such a shallow velocity zone may also produce strong site effects. For example, using the generic model overlaying a homogeneous layer, the horizontal-to-vertical spectral ratio $(\mathrm{H} / \mathrm{V})$ calculated with a computer program developed by García-Jerez et al. (2016) presents a strong maximum at $0.75 \mathrm{~Hz}$ and a secondary peak at $1.7 \mathrm{~Hz}$. Amplifications of the seismic motions in this frequency range are commonly observed at volcanoes (Mora et al., 2001). Moreover, low velocity near-surface layers generate marked path effects and wavefield distortions that are important to take into account when interpreting longperiod seismic events and carrying out moment tensor inversions (Bean et al., 2008; 2013).

Finally, the size, shape, and position of magma bodies beneath a volcanic structure are often estimated using isotropic elastic half-space "Mogi" models (e.g. Amelung et al., 2000; Pinel and Jaupart, 2003; Dzurisin, 2006; Albino et al., 2010). Although static elastic moduli may be more appropriate for such modelling (e.g. Manconi et al., 2010), the generic model described herein could be used to provide depth-dependent elastic parameters to refine models that use surface deformation to understand the migration and accumulation of magma.

\section{Conclusions}

Our knowledge of volcanic structures is strongly limited by the precision, resolution and penetration depth of the geophysical methods used to image volcanoes, as well as by logistical constraints. Moreover, the number of volcanoes for which structural studies have been undertaken is still limited. Further, the assessment of the physical properties of volcanic materials is a challenging task due to the diversity and microstructural complexity of volcanic rocks, and the fact that laboratory measurements are conducted on nominally intact rock samples. These factors have motivated the present metaanalysis of prior studies on the determination of seismic velocities using geophysical and petrophysical approaches. Although the number of studies considered here is not large enough to give strong statistical significance to this analysis, we can draw the following conclusions:

1) Within the set of models and measurements considered in this study, the range of values and behaviors of seismic velocities appear to be similar for andesitic, dacitic and basaltic volcanoes. They differ however for the tuffs from Campi Flegrei and Alban Hills.

2) The compilation of numerous velocity models and measurements presented here highlights the strong variability of the P- and S-wave velocities in volcanoes. This variability is demonstrably related to the diversity of materials that constitute volcanoes and reflects the 
complexity of the structures that can be retrieved by stratigraphic and geomorphological studies (e.g. Selles et al., 2015). Seismic velocity variability is found at all spatial scales down to a few meters as observed in seismic logs. This must be kept in mind when interpreting velocity models, which describe the structures either as a few homogeneous layers or as smoothed 3-D distributions of parameters. Due to the progressive compaction of volcanic materials with pressure, temperature and time (e.g. Quane et al., 2009; Vasseur et al., 2013; Heap et al., 2015a, b; Wadsworth et al., 2016; Kennedy et al., 2016; Heap et al., 2017b; Farquharson et al., 2017b), the variability of velocities tends to decrease with increasing depth. This suggests that the heterogeneity of these structures should also generally decrease with depth.

3) The values obtained by velocity measurement on rock samples in laboratory are systematically larger than those estimated by seismic methods and the average velocities measured by welllogging. Although these discrepancies can be easily explained by scaling problems due to the large structural differences between the volumes sampled in the various methods, it would be interesting, and challenging, to try to reconcile the results produced using the different techniques/approaches.

4) Direct in-situ measurements by well-logging in deep boreholes provide invaluable insight into the complexity of volcanic structures. More scientific drilling projects would be welcome, as well as publication of log data obtained for industrial purposes.

5) When averaging the seismic models, a general trend appears. The averaged seismic model is characterized by very low $\mathrm{P}$ - and S-waves velocities at the surface, a large increase in the first few hundred meters below the surface, before the velocity gradient becomes less pronounced at depth. This shallow, high-velocity-gradient layer is partly made of pyroclastic materials that are rapidly compacted and strengthened as pressure increases. The generic model proposed herein describes the velocity variations in the $500 \mathrm{~m}$-thick shallow layer for andesitic and basaltic volcanoes and can be used whenever no better information is available for a given volcano.

Finally, in order to improve our knowledge of the structure and of the mechanical behavior of volcanoes, we propose the following recommendations:

1) The analysis of the physical properties of volcanic rocks through laboratory experiments should be continued. In particular, it should be expanded to include more volcanoes. Special attention should be paid to the pressure-dependence of $V_{P}$ and $V_{S}$ of pyroclastic materials at pressures equivalent to the first hundreds of meters below the edifice surface and to the influence of pore shape and pore aspect ratio (e.g. Toksöz et al., 1976), factors known to vary considerably for volcanic rocks (e.g. Shea et al., 2010).

2) More seismic studies are necessary to improve the knowledge of the structure of specific volcanic edifices and to better understand the general behavior of these structures. To this end, the use of a combination of methods would provide improved images of volcanic edifices thanks to their complementary resolving capabilities and penetration depths.

3) Another meta-analysis of velocity estimations should be carried out to refine and extent toward deeper depths the generic model presented here as more seismic and laboratory experiments and well-logs become available. While a review of current tomographic models 
was out of the scope of the present work, further analysis should include 3-D images obtained by seismic tomography using body or surface waves.

\section{Acknowledgements}

M. Heap acknowledges an IDEX "Attractivité" grant (VOLPERM) and a "Congé pour recherche ou conversion thématique" (CRCT), both awarded by the University of Strasbourg. A. Kushnir acknowledges the ANR grant CANTARE (ANR-15-CE06-0014-01) and a Postgraduate ScholarshipDoctoral (CGSD3-444207-2013) provided by the Natural Sciences and Engineering Research Council of Canada (NSERC). M. Heap thanks Nick Varley, Sebastian Mueller, Olivier Spieler, and Yan Lavallée for the collection and provision of the materials from Volcán de Colima. A. Kushnir thanks Jean-Louis Bourdier and Caroline Martel for the provision of materials from Merapi; collection of materials from the 2010 and 2013 eruptions were conducted as part of the ANR project DoMerapi (ANR-12-BS060012). P. Lesage thanks Bernard Valette for stimulating discussions. Philip Benson and Gilberto Saccorotti are warmly acknowledged for their constructive and encouraging reviews. 


\section{References}

Adam, L., Wijk, K., Otheim, T., \& Batzle, M., 2013. Changes in elastic wave velocity and rock microstructure due to basalt-CO2-water reactions. J. Geophys. Res.: Solid Earth, 118(8), 4039-4047.

Adam, L., \& Otheim, T., 2013. Elastic laboratory measurements and modeling of saturated basalts. J. Geophys. Res.: Solid Earth, 118(3), 840-851.

Aki, K., 1957. Space and time spectra of stationary stochastic waves, with special reference to microtremors. Bull Earthq. Res. Inst. Tokyo Univ., 25: 415-457.

Albino, F., Pinel, V., \& Sigmundsson, F., 2010. Influence of surface load variations on eruption likelihood: application to two Icelandic subglacial volcanoes, Grímsvötn and Katla. Geophys. J. Int., 181(3), 15101524.

Amelung, F., Jónsson, S., Zebker, H., and Segall, P., 2000. Widespread uplift and 'trapdoor' faulting on Galapagos volcanoes observed with radar interferometry. Nature, 407(6807), 993-996.

Apuani, T., Corazzato, C., Cancelli, A., and Tibaldi, A., 2005. Physical and mechanical properties of rock masses at Stromboli: a dataset for volcano instability evaluation. Bull. Engineering Geology and the Environment, 64(4), 419.

Backus, G.E., 1962. Long-Wave Elastic Anisotropy Produced by Horizontal Layering. J. Geophys. Res., 67(11): 4427-4440.

Barclay, J., Rutherford, M. J., Carroll, M. R., Murphy, M. D., Devine, J. D., Gardner, J., and Sparks, R. S. J., 1998. Experimental phase equilibria constraints on pre-eruptive storage conditions of the Soufrière Hills magma. Geophys. Res. Lett., 25(18), 3437-3440.

Barmin, M.P., Ritzwoller, M.H. and Levshin, A.L., 2001. A fast and reliable method for surface wave tomography. Pure Appl. Geophys., 158(8): 1351-1375.

Bean, C.J., Lokmer, I. and O'Brien, G.S., 2008. Influence of near-surface volcanic structure on long-period seismic signals and on moment tensor inversions: Simulated examples from Mount Etna. J. Geophys. Res., 113: B08308, doi:08310.01029/02007JB005468.

Bean, C.J., De Barros, L., Lokmer, I., Métaxian, J.-P., O’Brien, G.S. and Murphy, S., 2013. Long-period seismicity in the shallow volcanic edifice formed from slow-rupture earthquakes. Nature Geoscience, 7: 71-75.

Biggs, J., Mothes, P., Ruiz, M., Amelung, F., Dixon, T. H., Baker, S., and Hong, S. H., 2010. Stratovolcano growth by co-eruptive intrusion: the 2008 eruption of Tungurahua Ecuador. Geophys. Res. Lett., 37(21).

Birch, F., 1960. The velocity of compression waves in rocks to 10 kilobars. J. Geophys. Res., 65: 1083.

Borgia, A., and Linneman, S. R., 1990. On the mechanisms of lava flow emplacement and volcano growth: Arenal, Costa Rica. In Lava flows and domes (pp. 208-243). Springer Berlin Heidelberg.

Brantut, N., 2018. Time-resolved tomography using acoustic emissions in the laboratory, and application to sandstone compaction. Geophys. J. Int. https://doi.org/10.1093/gji/ggy068.

Capon, J., 1969. High resolution frequency-wavenumber spectrum analysis. Proc. IEEE, 57: 1408-1418.

Chiarabba, C., Amato, A., Boschi, E., \& Barberi, F., 2000. Recent seismicity and tomographic modeling of the Mount Etna plumbing system. J. Geophys. Res.: Solid Earth, 105(B5), 10923-10938.

Chouet, B., 1996. New methods and future trends in seismological volcano monitoring. In: R. Scarpa and R.I. Tilling (Editors), Monitoring and mitigation of volcano hazards, pp. 23-97.

Chouet, B., Dawson, P., De Luca, G., Martini, M., Milana, G., Saccorotti, G. and Scarpa, R., 1998. Array analyses of seismic wavefields radiated by eruptive activity at Stromboli volcano, Italy, Felici Editore.

Colombier, M., Wadsworth, F. B., Gurioli, L., Scheu, B., Kueppers, U., Di Muro, A., and Dingwell, D. B., 2017. The evolution of pore connectivity in volcanic rocks. Earth Planet. Sc. Lett., 462, 99-109.

Cook, S. C. W., Kennedy, B. M., and Villeneuve, M. C., 2017. Engineering geology model of the Crater Lake outlet, Mt. Ruapehu, New Zealand, to inform rim breakout hazard, J. Volcanol. Geotherm. Res., https://doi.org/10.1016/j.volgeores.2017.12.006.

De Luca, G., Scarpa, R., Del Pezzo, E. and Simini, M., 1997. Shallow structure of Mt. Vesuvius volcano, Italy, from seismic array analysis. Geophys. Res. Lett., 24(4): 481-484.

Del Pezzo, E., Bianco, F. and Saccorotti, G., 2001. Separation of intrinsic and scattering Q for volcanic tremor: an application to Etna and Masaya volcanoes. Geophys. Res. Lett., 28(16): 3083-3086.

Devine, J. D., Murphy, M. D., Rutherford, M. J., Barclay, J., Sparks, R. S. J., Carroll, M. R., and Gardner, J. E., 1998. Petrologic evidence for pre-eruptive pressure-temperature conditions, and recent reheating, of andesitic magma erupting at the Soufriere Hills Volcano, Montserrat, WI. Geophys. Res. Lett., 25(19), 3669-3672.

Díaz-Moreno, A., Barberi, G., Cocina, O., Koulakov, I., Scarfi, L., Zuccarello, L., Prudencio, J., García-Yeguas, A., Alvarez, I., Garcia, L. and Ibáñez, J.M., 2017. New Insights on Mt. Etna's Crust and Relationship with the 
Regional Tectonic Framework from Joint Active and Passive P-Wave Seismic Tomography. Surveys in Geophysics. DOI 10.1007/s10712-017-9425-3

Dixon, J.P., Stihler, S.D., Power, J.A. and Searcy, C.K., 2010. Catalog of Earthquake Hypocenters at Alaskan Volcanoes: January 1 through December 31, 2009. U. S. Geological Survey Data Series 531.

Dzurisin, D., 2006. Volcano deformation: new geodetic monitoring techniques. Springer Science \& Business Media.

Eichelberger, J. C., Carrigan, C. R., Westrich, H. R., \& Price, R. H.,1986. Non-explosive silicic volcanism. Nature, 323(6089), 598-602.

Eichelberger, J.C., Vogel, T.A., Younker, L.W., Miller, C.D., Heiken, G.H. and Wohletz, K.H., 1988. Structure and Stratigraphy Beneath a Young Phreatic Vent: South Inyo Crater, Long Valley Caldera, California. J. Geophys. Res., 93(B11): 13208-13220.

Farquharson, J., Heap, M. J., Varley, N. R., Baud, P., and Reuschlé, T., 2015. Permeability and porosity relationships of edifice-forming andesites: a combined field and laboratory study. J. Volcanol. Geotherm. Res., 297, 52-68.

Farquharson, J. I., Heap, M. J., Lavallée, Y., Varley, N. R., \& Baud, P., 2016. Evidence for the development of permeability anisotropy in lava domes and volcanic conduits. J. Volcanol. Geotherm. Res., 323, 163-185.

Farquharson, J. I., Wadsworth, F. B., Heap, M. J., and Baud, P., 2017a. Time-dependent permeability evolution in compacting volcanic fracture systems and implications for gas overpressure. J. Volcanol. Geotherm. Res., 339, 81-97.

Farquharson, J. I., Baud, P., and Heap, M. J., 2017b. Inelastic compaction and permeability evolution in volcanic rock. Solid Earth, 8(2), 561.

Fortin, J., Stanchits, S., Vinciguerra, S. and Guéguen, Y., 2011. Influence of thermal and mechanical cracks on permeability and elastic wave velocities in a basalt from Mt. Etna volcano subjected to elevated pressure. Tectonophysics, 503: 60-74.

García-Jerez, A., Piña-Flores, J., Sánchez-Sesma, F.J., Luzón, F. and Perton, M., 2016. A computer code for forward calculation and inversion of the $\mathrm{H} / \mathrm{V}$ spectral ratio under the diffuse field assumption. Computers \& Geosciences, 97: 67-78.

Gardner, J. E., Rutherford, M., Carey, S., and Sigurdsson, H., 1995. Experimental constraints on pre-eruptive water contents and changing magma storage prior to explosive eruptions of Mount St Helens volcano. Bull. Volcanol., 57(1), 1-17.

Gaunt, H. E., Sammonds, P. R., Meredith, P. G., Smith, R., and Pallister, J. S., 2014. Pathways for degassing during the lava dome eruption of Mount St. Helens 2004-2008. Geology, 42(11), 947-950.

Gaunt, H. E., Sammonds, P.R., Meredith, P.G., Chadderton, A., 2016. Effect of temperature on the permeability of lava dome rocks from the 2004-2008 eruption of Mount St. Helens. Bull Volcanol, 78, 30.

Geyer, A., and Gottsmann, J., 2010. The influence of mechanical stiffness on caldera deformation and implications for the 1971-1984 Rabaul uplift (Papua New Guinea). Tectonophysics, 483(3), 399-412.

Gercek, H., 2007. Poisson's ratio values for rocks. International Journal of Rock Mechanics and Mining Sciences 44(1): 1-13.

Harnett, C.E., Benson, P.M., Rowley, P. and Fazio, M., 2018. Fracture and damage localization in volcanic edifice rocks from El Hierro, Stromboli and Tenerife, Nature Sci. Rep., 8, 1942, doi: 10.1038/ s41598-018-20442w.

Hautmann, S., Gottsmann, J., Sparks, R. S. J., Mattioli, G. S., Sacks, I. S., and Strutt, M. H., 2010. Effect of mechanical heterogeneity in arc crust on volcano deformation with application to Soufrière Hills Volcano, Montserrat, West Indies. J. Geophys. Res.: Solid Earth, 115(B9).

Heap, M.J., Lavallée, Y., Petrakova, L., Baud, P., Reuschlé, T., Varley, N.R. and Dingwell, D.B., $2014 a$. Microstructural controls on the physical and mechanical properties of edifice-forming andesites at Volcán de Colima, Mexico. J. Geophys. Res., 119(4): 2925-2963.

Heap, M.J., Baud, P., Meredith, P.G., Vinciguerra, S. and Reuschlé, T., 2014b. The permeability and elastic moduli of tuff from Campi Flegrei, Italy: implications for ground deformation modelling. Solid Earth, 5(1): 2544.

Heap, M.J., Farquharson, J.I., Baud, P., Lavallée, Y. and Reuschlé, T., 2015a. Fracture and compaction of andesite in a volcanic edifice. Bull. Volcanol., 77: 55.

Heap, M. J., Farquharson, J. I., Wadsworth, F. B., Kolzenburg, S., and Russell, J. K., 2015b. Timescales for permeability reduction and strength recovery in densifying magma. Earth Planet. Sc. Lett., 429, 223-233.

Heap, M. J., and Kennedy, B. M., 2016. Exploring the scale-dependent permeability of fractured andesite. Earth Planet. Sc. Lett., 447, 139-150. 
Heap, M. J., Kennedy, B. M., Farquharson, J. I., Ashworth, J., Mayer, K., Letham-Brake, M., and Siratovich, P., 2017a. A multidisciplinary approach to quantify the permeability of the Whakaari/White Island volcanic hydrothermal system (Taupo Volcanic Zone, New Zealand). J. Volcanol. Geotherm. Res., 332, 88-108.

Heap, M. J., Violay, M., Wadsworth, F. B., and Vasseur, J., 2017b. From rock to magma and back again: The evolution of temperature and deformation mechanism in conduit margin zones. Earth Planet. Sc. Lett., 463, 92-100.

Ikeda, R., Kajiwara, T., Omura, T. and Hickman, S., 2008. Physical rock properties in and around a conduit zone by well-logging in the Unzen Scientific Drilling Project, Japan. J. Volcanol. Geotherm. Res., 175: 13-19.

Ito, H., DeVilbiss, J. and Nur, A., 1979. Compressional and shear waves in saturated rock during water-steam transition. J. Geophys. Res., 84: 4731-4735.

Jolly, A., Page, R.A. and Power, J.A., 1994. Seismicity and stress in the vicinity of Mount Spurr volcano, south central Alaska. J. Geophys. Res., 99(B8): 15305-15318.

Judenherc, S. and Zollo, A., 2004. The Bay of Naples (southern Italy): Constraints on the volcanic structures inferred from a dense seismic survey. J. Geophys. Res. Solid Earth, 109(B10): B10312.

Kaneko, T., Wooster, M. J., and Nakada, S., 2002. Exogenous and endogenous growth of the Unzen lava dome examined by satellite infrared image analysis. J. Volcanol. Geotherm. Res., 116(1), 151-160.

Kennedy, B.M., Wadsworth, F.B., Vasseur, J., Schipper, C.I., Jellinek, A.M., von Aulock, F.W., Hess, K.U., Russell, J.K., Lavallée, Y., Nichols, A.R. and Dingwell, D.B., 2016. Surface tension driven processes densify and retain permeability in magma and lava. Earth Planet. Sc. Lett., 433, 116-124.

Kissling, E., Ellsworth, W.L., Eberhart-Phillips, D. and Kradolfer, U., 1994. Initial reference models in local earthquake tomography. J. Geophys. Res., 99: 19635-19646.

Kolzenburg, S., Heap, M.J., Lavallée, Y., Russell, J.K., Meredith, P.G. and Dingwell, D.B., 2012. Strength and permeability recovery of tuffisite-bearing andesite. Solid Earth, 3: 191-198.

Kushnir, A. R., Martel, C., Bourdier, J. L., Heap, M. J., Reuschlé, T., Erdmann, S., and Cholik, N., 2016. Probing permeability and microstructure: Unravelling the role of a low-permeability dome on the explosivity of Merapi (Indonesia). J. Volcanol. Geotherm. Res., 316, 56-71.

Kushnir, A. R., Martel, C., Champallier, R., and Arbaret, L., 2017a. In situ confirmation of permeability development in shearing bubble-bearing melts and implications for volcanic outgassing. Earth Planet. Sc. Lett., 458, 315-326.

Kushnir, A. R., Martel, C., Champallier, R., and Wadsworth, F. B., 2017b. Permeability evolution in variably glassy basaltic andesites measured under magmatic conditions. Geophys. Res. Lett., 44(20).

La Rocca, M., Petrosino, S., Saccorotti, G., Simini, M., Ibáñez, J., Almendros, J. and Del Pezzo, E., 2000. Location of the source and shallow velocity model deduced from the explosion quakes recorded by two antennas at Stromboli volcano. Phys. Chem. Earth, 25(9-11): 731-735.

Lahr, J.C., Chouet, B.A., Stephens, J.A., Power, J.A. and Page, R.A., 1994. Earthquake classification, location and error analysis in a volcanic environment: implications for the magmatic system of the 1989-1990 eruptions at Redoudt volcano, Alaska. J. Volcanol. Geotherm. Res., 62: 137-151.

Lavallée, Y., Benson, P. M., Heap, M. J., Hess, K. U., Flaws, A., Schillinger, B., and Dingwell, D. B., 2013. Reconstructing magma failure and the degassing network of dome-building eruptions. Geology, 41(4), 515-518.

Lengliné, O., Duputel, Z., and Ferrazzini, V., 2016. Uncovering the hidden signature of a magmatic recharge at Piton de la Fournaise volcano using small earthquakes. Geophys. Res. Lett., 43(9), 4255-4262.

Lesage, P., Reyes-Dávila, G.A. and Arámbula-Mendoza, R., 2014. Large tectonic earthquakes induce sharp temporary decreases in seismic velocity in Volcán de Colima, Mexico. J. Geophys. Res., 119(5): 43604376.

Lockner, D.A., Walsh, J.B. and Byerlee, J.D., 1977. Changes in seismic velocity and attenuation during deformation of granite. J. Geophys. Res., 82(33): 5374-5378.

Manconi, A., Walter, T. R., and Amelung, F., 2007. Effects of mechanical layering on volcano deformation. Geophys. J. Int., 170(2), 952-958.

Manconi, A., Walter, T. R., Manzo, M., Zeni, G., Tizzani, P., Sansosti, E., \& Lanari, R., 2010. On the effects of 3-D mechanical heterogeneities at Campi Flegrei caldera, southern Italy. Journal of Geophysical Research: Solid Earth, 115(B8).

Mariucci, M.T., Pierdominici, S., Pizzino, L., Marra, F. and Montone, P., 2008. Looking into a volcanic area: An overview on the $350 \mathrm{~m}$ scientific drilling at Colli Albani (Rome, Italy). J. Volcanol. Geotherm. Res., 176: 225-240. 
Martel, C., Pichavant, M., Bourdier, J. L., Traineau, H., Holtz, F., and Scaillet, B., 1998. Magma storage conditions and control of eruption regime in silicic volcanoes: experimental evidence from Mt. Pelée. Earth Planet. Sc. Lett., 156(1), 89-99.

Mavko, G., Mukerji, T. and Godfrey, N., 1995. Predicting stress-induced velocity anisotropy in rocks Geophysics, 60(4): 1081-1087.

McNutt, S.R. and Jacob, K.H., 1986. Determination of large-scale velocity structure of the crust and upper mantle in the vicinity of Pavlof volcano, Alaska. J. Geophys. Res., 91(B5): 5013-5022.

Métaxian, J.-P., Lesage, P. and Dorel, J., 1997. The permanent tremor of Masaya volcano, Nicaragua : Wave field analysis and source location. J. Geophys. Res., 102: 22529-22545.

Mizutani, H., and H. Kanamori, 1964. Variation of elastic wave velocity and attenuation property near the melting temperature, J. Phys. Earth, 12, 43-49.

Mora, M., Lesage, P., Dorel, J., Bard, P.-Y., Métaxian, J.-P., Alvarado, G.E. and Leandro, C., 2001. Detection of seismic site effects by using H/V spectral ratios at Arenal volcano (Cost Rica). Geophys. Res. Lett., 28(15): 2991-2994.

Mora, M., Lesage, P., Valette, B., Alvarado, G., Leandro, C., Métaxian, J.-P. and Dorel, J., 2006. Shallow velocity structure and seismic site effects at Arenal volcano, Costa Rica. J. Volcanol. Geotherm. Res., 152: 121139.

Mordret, A., Rivet, D., Landès, M. and Shapiro, N., 2015. Three-dimensional shear velocity anisotropic model of Piton de la Fournaise Volcano (La Réunion Island) from ambient seismic noise. J. Geophys. Res., 120: 406-427.

Mueller, S., Melnik, O., Spieler, O., Scheu, B., and Dingwell, D. B., 2005. Permeability and degassing of dome lavas undergoing rapid decompression: an experimental determination. Bull. Volcanol., 67(6), 526-538.

Nakada, S., Uto, K., Sakuma, S., Eichelberger, J.C. and Shimizu, H., 2005. Scientific results of conduit drilling in the Unzen scientific drilling project (USDP). Scientific Drilling, 1: 18-22.

Nara, Y., Meredith, P. G., Yoneda, T., and Kaneko, K., 2011. Influence of macro-fractures and micro-fractures on permeability and elastic wave velocities in basalt at elevated pressure. Tectonophysics, 503(1), 52-59.

Nardone, L. and Maresca, R., 2011. Shallow Velocity Structure and Site Effects at Mt. Vesuvius, Italy, from HVSR and Array Measurements of Ambient Vibrations Bull. Seismol. Soc Am., 101(4): 1465-1477.

Nur, A., 1971. Effects of Stress on Velocity Anisotropy in Rocks with Cracks. J. Geophys. Res., 76(8): 2022-2034.

Odbert, H., Taisne, B., and Gottsmann, J., 2015. Deposit loading and its effect on co-eruptive volcano deformation. Earth Planet. Sc. Lett., 413, 186-196.

Perrier, L., Métaxian, J.-P., Battaglia, J. and Garaebiti, E., 2012. Estimation of the near-surface velocity structure of the Yasur-Yenkahe volcanic complex, Vanuatu. J. Volcanol. Geotherm. Res., 227-228: 50-60.

Pinel, V., and Jaupart, C., 2003. Magma chamber behavior beneath a volcanic edifice. J. Geophys. Res.: Solid Earth, 108(B2).

Pola, A., Crosta, G., Fusi, N., Barberini, V., and Norini, G., 2012. Influence of alteration on physical properties of volcanic rocks. Tectonophysics, 566, 67-86.

Quane, S. L., Russell, J. K., \& Friedlander, E. A., 2009. Time scales of compaction in volcanic systems. Geology, 37(5), 471-474.

Rossetto, V., Margerin, L., Planes, T. and Larose, E., 2011. Locating a weak change using diffuse waves: Theoretical approach and inversion procedure. J. Applied Physics, 109(1): 034903.

Rust, A. C., and Cashman, K. V., 2004. Permeability of vesicular silicic magma: inertial and hysteresis effects. Earth Planet. Sc. Lett., 228(1), 93-107.

Rust, A. C., Cashman, K. V., and Wallace, P. J., 2004. Magma degassing buffered by vapor flow through brecciated conduit margins. Geology, 32(4), 349-352.

Saar, M. O., and Manga, M., 1999. Permeability-porosity relationship in vesicular basalts. Geophys. Res. Lett., 26(1), 111-114.

Saccorotti, G., Maresca, R. and Del Pezzo, E., 2001. Array analyses of seismic noise at Mt. Vesuvius Volcano, Italy. J. Volcanol. Geotherm. Res., 110: 79-100.

Saccorotti, G., Chouet, B. and Dawson, P., 2003. Shallow velocity models at Kilauea Volcano, Hawaii, determined from array analysis of tremor. Geophys. J. Int., 152(3): 633-648.

Saccorotti, G., Zuccarello, L., Del Pezzo, E., Ibáñez, J.M. and Gresta, S., 2004. Quantitative analysis of the tremor wavefield at Etna volcano, Italy. J. Volcanol. Geotherm. Res., 136: 223-245.

Sakuma, S., Kajiwara, T., Nakada, S., Uto, K. and Shimizu, H., 2008. Drilling and logging results of USDP-4 Penetration into the volcanic conduit of Unzen Volcano, Japan. J. Volcanol. Geotherm. Res., 175: 1-12. 
Sánchez-Sesma, F.J., Rodríguez, M., Iturrarán-Viveros, U., Luzón, F., Campillo, M., Margerin, L., García-Jerez, A., Suarez, M., Santoyo, M.A. and Rodríguez-Castellanos, A., 2011. A theory for microtremor h/v spectral ratio: application for a layered medium. Geophys. J. Int., 186(1): 221-225.

Schubnel, A. and Guéguen, Y., 2003. Dispersion and anisotropy of elastic waves in cracked rocks. J. Geophys. Res., 108(B2): 2101.

Scheu, B., Kern, H., Spieler, O. and Dingwell, D.B., 2006. Temperature dependence of elastic P- and S-wave velocities in porous Mt. Unzen dacite. J. Volcanol. Geotherm. Res., 153: 136-147.

Selles, A., Deffontaines, B., Hendrayana, H. and Violette, S., 2015. The eastern flank of the Merapi volcano (Central Java, Indonesia): Architecture and implications of volcaniclastic deposits. J. Asian Earth Sciences, 108: 33-47.

Shea, T., Houghton, B. F., Gurioli, L., Cashman, K. V., Hammer, J. E., and Hobden, B. J., 2010. Textural studies of vesicles in volcanic rocks: an integrated methodology. J. Volcanol. Geotherm. Res., 190(3), 271-289.

Siratovich, P. A., Heap, M. J., Villenueve, M. C., Cole, J. W., and Reuschlé, T., 2014. Physical property relationships of the Rotokawa Andesite, a significant geothermal reservoir rock in the Taupo Volcanic Zone, New Zealand. Geothermal Energy, 2(1), 10.

Spica, Z., Caudron, C., Perton, M., Lecocq, T., Camelbeeck, T., Legrand, D., Piña-Flores, J., Iglesias, A. and Kamil Syahbana, D., 2015. Velocity models and site effects at Kawah Ijen volcano and Ijen caldera (Indonesia) determined from ambient noise cross-correlations and directional energy density spectral ratios. J. Volcanol. Geotherm. Res., 302: 173-189.

Spica, Z., Perton, M. and Legrand, D., 2016. Anatomy of the Colima volcano magmatic system, Mexico. Earth Planet. Sc. Lett.

Stanchits, S., Vinciguerra, S. and Dresen, G., 2006. Ultrasonic Velocities, Acoustic Emission Characteristics and Crack Damage of Basalt and Granite. Pure Appl. Geophys., 163: 974-993.

Strollo, R., Nunziata, C., lannotta, A. and lannotta, D., 2015. The uppermost crust structure of Ischia (southern Italy) from ambient noise Rayleigh waves. J. Volcanol. Geotherm. Res., 297: 39-51.

Thelen, W., Crosson, R.S. and Creager, K.C., 2008. Absolute and relative locations of earthquakes at Mount St. Helens, Washington, using continuous data: implications for magmatic processes. In: D.R. Sherrod, W.E. Scott and P.H. Stauffer (Editors), A volcano rekindled: the renewed eruption of Mount St. Helens, 20042006. U.S. Geological Survey Professional Paper.

Thomas, M. E., Petford, N., and Bromhead, E. N., 2004. Volcanic rock-mass properties from Snowdonia and Tenerife: implications for volcano edifice strength. J. Geological Society, 161(6), 939-946.

Toksöz, M. N., Cheng, C. H., \& Timur, A. (1976). Velocities of seismic waves in porous rocks. Geophysics, 41(4), 621-645.

Tramelli, A., Galluzzo, D., Del Pezzo, E. and Di Vito, M., 2010. A detailed study of the site effects in the volcanic area of Campi Flegrei using empirical approaches. Geophys. J. Int., 182: 1073-1086.

Tripoli, B. A., Cordonnier, B., Zappone, A., and Ulmer, P., 2016. Effects of crystallization and bubble nucleation on the seismic properties of magmas. Geochemistry, Geophysics, Geosystems, 17(2), 602-615.

Vanorio, T., Prasad, M., Patella, D. and Nur, A., 2002. Ultrasonic velocity measurements in volcanic rocks: correlation with microtexture. Geophys. J. Int., 149(1): 22-36.

Vanorio, T., Virieux, J., Capuano, P. and Russo, G., 2005. Three-dimensional seismic tomography from P wave and $S$ wave microearthquake travel times and rock physics characterization of the Campi Flegrei Caldera. J. Geophys. Res, 110(B3): B03201 03210.01029/02004JB003102.

Vasseur, J., Wadsworth, F. B., Lavallée, Y., Hess, K. U., \& Dingwell, D. B., 2013. Volcanic sintering: timescales of viscous densification and strength recovery. Geophysical Research Letters, 40(21), 5658-5664.

Vinciguerra, S., Trovato, C., Meredith, P.G. and Benson, P.M., 2005. Relating seismic velocities, thermal cracking and permeability in Mt. Etna and Iceland basalts. Intern. J. Rock Mechanics \& Mining Sc., 42: 900-910.

Vinciguerra, S., Trovato, C., Meredith, P.G., Benson, P.M., Troise, C. and De Natale, G., 2006. Understanding the Seismic Velocity Structure of Campi Flegrei Caldera (Italy): From the Laboratory to the Field Scale. Pure Appl. Geophys., 163: 2205-2221.

Vinciguerra, S., Del Gaudio, P., Mariucci, M.T., Marra, F., Meredith, P.G., Montone, P., Pierdominici, S. and Scarlato, P., 2009. Physical properties of tuffs from a scientific borehole at Alban hills volcanic district (central Italy). Tectonophysics, 471: 161-169.

Voight, B., 2000. Structural stability of andesite volcanoes and lava domes. Philosophical Transactions of the Royal Society of London A: Mathematical, Physical and Engineering Sciences, 358(1770), 1663-1703.

Wadsworth, F. B., Vasseur, J., Scheu, B., Kendrick, J. E., Lavallée, Y., \& Dingwell, D. B., 2016. Universal scaling of fluid permeability during volcanic welding and sediment diagenesis. Geology, 44(3), 219-222. 
Wegler, U. and Lühr, B.-G., 2001. Scattering behaviour at Merapi volcano (Java) revealed from an active experiment. Geophys. J. Int., 145: 579-592.

Winkler, K.W., 1983. Frequency Dependent Ultrasonic Properties of High-Porosity Sandstones. J. Geophys. Res. Solid Earth, 88(B11): 9493-9499.

Winkler, K.W., 1986. Estimates of velocity dispersion between seismic and ultrasonic frequencies. Geophysics, 51(1): 183-189.

Wyering, L. D., Villeneuve, M. C., Wallis, I. C., Siratovich, P. A., Kennedy, B. M., Gravley, D. M., and Cant, J. L., 2014. Mechanical and physical properties of hydrothermally altered rocks, Taupo Volcanic Zone, New Zealand. J. Volcanol. Geotherm. Res., 288, 76-93.

Zamora, M., Sartoris, G. and Chelini, W., 1994. Laboratory measurements of ultrasonic wave velocities in rocks from the Campi Flegrei volcanic system and their relation to other field data. J. Geophys. Res., 99(B7): 13553-13561.

Zimmerman, R.W., Somerton, W.H. and King, M.S., 1986. Compressibility of porous rocks. J. Geophys. Res., 91(B12): 12765-12777.

Zollo, A., Judenherc, S., Auger, E., D'Auria, L., Virieux, J., Capuano, P., Chiarabba, C., de Franco, R., Makris, J., Michelini, A. and Musacchio, G., 2003. Evidence for the buried rim of Campi Flegrei caldera from 3-d active seismic imaging. Geophys. Res. Lett., 30(19): 2002.

Zulfakriza, Z., Saygin, E., Cummins, P.R., Widiyantoro, S., Nugraha, A.D., Lühr, B.-G. and Bodin, T., 2014. Upper crustal structure of central Java, Indonesia, from transdimensional seismic ambient noise tomography. Geophys. J. Int., 197: 630-635. 


\begin{tabular}{|c|c|c|c|c|c|c|c|}
\hline Volcano & Type & $V p$ & Vs & Max depth & Method & $\mathbf{N}$ & Reference \\
\hline Arenal & $A$ & $x$ & $x$ & 500 & SPAC & 3 & Mora et al., 2006 \\
\hline Yasur & B & $x$ & $x$ & 150 & SPAC & 7 & Perrier, 2012 \\
\hline Masaya & B & $x$ & $x$ & 800 & SPAC & 3 & Métaxian et al., 1997 \\
\hline Stromboli & B & $x$ & $x$ & 300 & SPAC & 1 & Chouet et al., 1998 \\
\hline Stromboli & B & $x$ & $x$ & 250 & Surface waves & 4 & La Rocca et al., 2000 \\
\hline Vesuvius & $A$ & $x$ & $x$ & 400 & SPAC & 1 & De Lucca et al., 1997 \\
\hline Vesuvius & $A$ & $x$ & $x$ & 400 & SPAC & 1 & Saccarotti et al., 2001 \\
\hline Vesuvius & $A$ & & $x$ & 200 & SPAC, f-k & 1 & Nardone et al., 2001 \\
\hline Kilauea & B & & $x$ & 500 & SPAC & 2 & Saccorotti et al., 2003 \\
\hline Etna & B & & $x$ & $\sim 450$ & SPAC & 2 & Saccorotti et al., 2004 \\
\hline Ischia & C & & $x$ & 1000 & $\begin{array}{l}\text { Surface waves, } \\
\text { noise correlation }\end{array}$ & 11 & Strollo et al., 2015 \\
\hline Campi Flegrei & $\mathrm{C}$ & & $x$ & $100-200$ & HVSR & 4 & Tramelli et al., 2010 \\
\hline Campi Flegrei & C & $x$ & & 4700 & Body waves & 1 & Zollo et al., 2003 \\
\hline Bay of Naples & C & $x$ & & 5000 & Body waves & 1 & Judenherc \& Zollo, 2004 \\
\hline Ijen & C & & $x$ & 3500 & $\begin{array}{c}\text { Surface waves, } \\
\text { noise correlation, } \\
\text { HVSR }\end{array}$ & 2 & Spica et al., 2015 \\
\hline Unzen & $A$ & $x$ & $x$ & 1500 & Well-logging & 1 & Sakuma et al., 2008 \\
\hline Alban hills & $\mathrm{C}$ & $x$ & & 110 & Well-logging & & Vinciguerra et al., 2009 \\
\hline Campi Flegrei & C & $x$ & $x$ & 0 & Lab experiments & 10 dry \& wet & Zamora et al., 1994 \\
\hline Campi Flegrei & $\mathrm{C}$ & $x$ & $x$ & $3500(1400)$ & Lab experiments & 2 wet & Heap et al., 2014b \\
\hline Campi Flegrei & C & $x$ & $x$ & $3000(1600)$ & Lab experiments & 11 dry & Vanorio et al., 2002 \\
\hline Campi Flegrei & C & $x$ & $x$ & $5000(1600)$ & Lab experiments & $8 V p+5 V s d r y$ & Vinciguerra et al., 2006 \\
\hline Etna & B & $x$ & $x$ & $3000(2600)$ & Lab experiments & 12 dry & Vanorio et al., 2002 \\
\hline Etna & B & $x$ & $x$ & $3500(2000)$ & Lab experiments & 4 dry +7 wet & Vinciguerra et al., 2005 \\
\hline Etna & B & $x$ & $x$ & $9000(2000)$ & Lab experiments & 2 dry +2 wet & Fortin et al., 2011 \\
\hline Etna & B & $\mathrm{x}$ & & $6000(2000)$ & Lab experiments & 1 dry & Stanchits et al., 2006 \\
\hline Colima & A & $x$ & $x$ & $1350(2400)$ & Lab experiments & 1 dry & Heap et al., 2014a \\
\hline Colima & $A$ & $x$ & $x$ & $1750(2820)$ & Lab experiments & 5 wet & Kolzenburg et al., 2012 \\
\hline Colima & $A$ & $x$ & & 40 & Lab experiments & 5 dry & this study \\
\hline Merapi & $A$ & $x$ & $x$ & 40 & Lab experiments & 25 dry & this study \\
\hline Unzen & $A$ & $x$ & $x$ & $4000(2200)$ & Lab experiments & 1 dry & Scheu et al., 2006 \\
\hline
\end{tabular}

Table 1. Data used in this study. Type of volcano: (A) Andesitic or dacitic, (B) Basaltic, and (C) Caldera. Maximal depth or equivalent depth obtained by model or experiment (in meters). The density used to convert pressure in depth is indicated in parenthesis for laboratory experiments. $\mathrm{N}$ : number of models or samples. 


\begin{tabular}{|c|c|c|c|c|c|}
\hline Rock type & $\begin{array}{c}\text { Connected } \\
\text { porosity (\%) }\end{array}$ & $V_{p}\left(k m \cdot s^{-1}\right)$ & $\mathrm{V}_{\mathrm{s}}\left(\mathrm{km} \cdot \mathrm{s}^{-1}\right)$ & $\mathrm{V}_{\mathrm{p}} / \mathrm{V}_{\mathrm{s}}$ ratio & Volcano (sample) \\
\hline Andesite & 8.8 & 2.43 & - & - & Volcán de Colima (A5) \\
\hline Andesite & 11.7 & 2.35 & - & - & Volcán de Colima (A5) \\
\hline Andesite & 8.9 & 2.38 & - & - & Volcán de Colima (A5) \\
\hline Andesite & 13 & 2.38 & - & - & Volcán de Colima (A5) \\
\hline Andesite & 11.1 & 2.22 & - & - & Volcán de Colima (A5) \\
\hline Andesite & 9.8 & 2.31 & - & - & Volcán de Colima (A5) \\
\hline Andesite & 11.2 & 2.42 & - & - & Volcán de Colima (A5) \\
\hline Andesite & 11.2 & 2.34 & - & - & Volcán de Colima (A5) \\
\hline Andesite & 8.8 & 2.28 & - & - & Volcán de Colima (A5) \\
\hline Andesite & 8.7 & 2.5 & - & - & Volcán de Colima (A5) \\
\hline Andesite & 8.2 & 2.53 & - & - & Volcán de Colima (A5) \\
\hline Andesite & 10.6 & 2.42 & - & - & Volcán de Colima (A5) \\
\hline Andesite & 8.9 & 2.43 & - & - & Volcán de Colima (A5) \\
\hline Andesite & 9.8 & 2.77 & - & - & Volcán de Colima (A5) \\
\hline Andesite & 8 & 2.94 & - & - & Volcán de Colima (A5) \\
\hline Andesite & 8.2 & 2.68 & - & - & Volcán de Colima (A5) \\
\hline Andesite & 11.2 & 2.76 & - & - & Volcán de Colima (A5) \\
\hline Andesite & 9.7 & 2.72 & - & - & Volcán de Colima (A5) \\
\hline Andesite & 9.5 & 2.67 & - & - & Volcán de Colima (A5) \\
\hline Andesite & 12.3 & 2.72 & - & - & Volcán de Colima (A5) \\
\hline Andesite & 8.4 & 2.78 & - & - & Volcán de Colima (A5) \\
\hline Andesite & 9.4 & 2.74 & - & - & Volcán de Colima (A5) \\
\hline Andesite & 7.8 & 2.73 & - & - & Volcán de Colima (A5) \\
\hline Andesite & 9.2 & 2.79 & - & - & Volcán de Colima (A5) \\
\hline Andesite & 7.7 & 2.76 & - & - & Volcán de Colima (A5) \\
\hline Andesite & 9.2 & 2.71 & - & - & Volcán de Colima (A5) \\
\hline Andesite & 8.6 & 2.73 & - & - & Volcán de Colima (A5) \\
\hline Andesite & 8.5 & 2.91 & - & - & Volcán de Colima (A5) \\
\hline Andesite & 8.8 & 2.84 & - & - & Volcán de Colima (A5) \\
\hline Andesite & 9.3 & 2.89 & - & - & Volcán de Colima (A5) \\
\hline Andesite & 6.7 & 2.79 & - & - & Volcán de Colima (A5) \\
\hline Andesite & 9.6 & 3.01 & - & - & Volcán de Colima (A5) \\
\hline Andesite & 9.8 & 2.7 & - & - & Volcán de Colima (A5) \\
\hline Andesite & 9.4 & 2.92 & - & - & Volcán de Colima (A5) \\
\hline Andesite & 8.1 & 2.91 & - & - & Volcán de Colima (A5) \\
\hline Andesite & 6.9 & 2.78 & - & - & Volcán de Colima (A5) \\
\hline Andesite & 8.5 & 2.54 & - & - & Volcán de Colima (A5) \\
\hline Andesite & 9 & 2.7 & - & - & Volcán de Colima (A5) \\
\hline Andesite & 8.3 & 2.53 & - & - & Volcán de Colima (A5) \\
\hline Andesite & 8.9 & 2.96 & - & - & Volcán de Colima (B4) \\
\hline Andesite & 8.7 & 3 & - & - & Volcán de Colima (B4) \\
\hline Andesite & 9.3 & 2.84 & - & - & Volcán de Colima (B4) \\
\hline Andesite & 10.5 & 2.68 & - & - & Volcán de Colima (B4) \\
\hline Andesite & 8.2 & 2.71 & - & - & Volcán de Colima (B4) \\
\hline Andesite & 8.2 & 2.56 & - & - & Volcán de Colima (B5) \\
\hline Andesite & 7.9 & 2.5 & - & - & Volcán de Colima (B5) \\
\hline
\end{tabular}




\begin{tabular}{|c|c|c|c|c|c|}
\hline Andesite & 8.1 & 2.67 & - & - & Volcán de Colima (B5) \\
\hline Andesite & 7.7 & 2.54 & - & - & Volcán de Colima (B5) \\
\hline Andesite & 7.9 & 2.5 & - & - & Volcán de Colima (B5) \\
\hline Andesite & 7.9 & 2.58 & - & - & Volcán de Colima (B5) \\
\hline Andesite & 8.2 & 2.62 & - & - & Volcán de Colima (B5) \\
\hline Andesite & 7.7 & 2.53 & - & - & Volcán de Colima (B5) \\
\hline Andesite & 8.1 & 2.79 & - & - & Volcán de Colima (B5) \\
\hline Andesite & 7.6 & 2.78 & - & - & Volcán de Colima (B5) \\
\hline Andesite & 7.8 & 2.77 & - & - & Volcán de Colima (B5) \\
\hline Andesite & 7.6 & 2.73 & - & - & Volcán de Colima (B5) \\
\hline Andesite & 7.6 & 2.65 & - & - & Volcán de Colima (B5) \\
\hline Andesite & 7.6 & 2.6 & - & - & Volcán de Colima (B5) \\
\hline Andesite & 7.6 & 2.57 & - & - & Volcán de Colima (B5) \\
\hline Andesite & 7.7 & 2.59 & - & - & Volcán de Colima (B5) \\
\hline Andesite & 7.4 & 2.79 & - & - & Volcán de Colima (B5) \\
\hline Andesite & 7.6 & 2.8 & - & - & Volcán de Colima (B5) \\
\hline Andesite & 7.4 & 2.66 & - & - & Volcán de Colima (B5) \\
\hline Andesite & 7.3 & 2.73 & - & - & Volcán de Colima (B5) \\
\hline Andesite & 7.7 & 2.61 & - & - & Volcán de Colima (B5) \\
\hline Andesite & 7.9 & 2.65 & - & - & Volcán de Colima (B5) \\
\hline Andesite & 7.5 & 2.82 & - & - & Volcán de Colima (B5) \\
\hline Andesite & 7.3 & 2.74 & - & - & Volcán de Colima (B5) \\
\hline Andesite & 7.4 & 2.76 & - & - & Volcán de Colima (B5) \\
\hline Andesite & 7.5 & 2.73 & - & - & Volcán de Colima (B5) \\
\hline Andesite & 7.4 & 2.63 & - & - & Volcán de Colima (B5) \\
\hline Andesite & 18.7 & 2.38 & - & - & Volcán de Colima (C8) \\
\hline Andesite & 17.9 & 2.47 & - & - & Volcán de Colima (C8) \\
\hline Andesite & 17.6 & 2.43 & - & - & Volcán de Colima (C8) \\
\hline Andesite & 16 & 2.39 & - & - & Volcán de Colima (C8) \\
\hline Andesite & 17.9 & 2.49 & - & - & Volcán de Colima (C8) \\
\hline Andesite & 18.6 & 2.49 & - & - & Volcán de Colima (C8) \\
\hline Andesite & 17.8 & 2.46 & - & - & Volcán de Colima (C8) \\
\hline Andesite & 17.6 & 2.46 & - & - & Volcán de Colima (C8) \\
\hline Andesite & 17.8 & 2.43 & - & - & Volcán de Colima (C8) \\
\hline Andesite & 15.7 & 2.68 & - & - & Volcán de Colima (C8) \\
\hline Andesite & 15.3 & 2.87 & - & - & Volcán de Colima (C8) \\
\hline Andesite & 16.2 & 2.64 & - & - & Volcán de Colima (C8) \\
\hline Andesite & 16.4 & 2.75 & - & - & Volcán de Colima (C8) \\
\hline Andesite & 16.3 & 2.62 & - & - & Volcán de Colima (C8) \\
\hline Andesite & 16.7 & 2.65 & - & - & Volcán de Colima (C8) \\
\hline Andesite & 16.7 & 2.63 & - & - & Volcán de Colima (C8) \\
\hline Andesite & 15.5 & 2.66 & - & - & Volcán de Colima (C8) \\
\hline Andesite & 15.2 & 2.57 & - & - & Volcán de Colima (C8) \\
\hline Andesite & 15.5 & 2.67 & - & - & Volcán de Colima (C8) \\
\hline Andesite & 15.8 & 2.6 & - & - & Volcán de Colima (C8) \\
\hline Andesite & 16.7 & 2.83 & - & - & Volcán de Colima (C8) \\
\hline Andesite & 16 & 2.78 & - & - & Volcán de Colima (C8) \\
\hline Andesite & 15.9 & 2.64 & - & - & Volcán de Colima (C8) \\
\hline
\end{tabular}




\begin{tabular}{|c|c|c|c|c|c|}
\hline Andesite & 15.9 & 2.72 & - & - & Volcán de Colima (C8) \\
\hline Andesite & 16.2 & 2.69 & - & - & Volcán de Colima (C8) \\
\hline Andesite & 15.5 & 2.8 & - & - & Volcán de Colima (C8) \\
\hline Andesite & 16.8 & 2.66 & - & - & Volcán de Colima (C8) \\
\hline Andesite & 19.4 & 2.5 & - & - & Volcán de Colima (C8) \\
\hline Andesite & 17.6 & 2.77 & - & - & Volcán de Colima (C8) \\
\hline Andesite & 16.5 & 2.63 & - & - & Volcán de Colima (C8) \\
\hline Andesite & 19 & 2.6 & - & - & Volcán de Colima (C8) \\
\hline Andesite & 18.5 & 2.72 & - & - & Volcán de Colima (C8) \\
\hline Andesite & 15.7 & 2.52 & - & - & Volcán de Colima (C8) \\
\hline Andesite & 27.8 & 2.19 & - & - & Volcán de Colima (LAH4) \\
\hline Andesite & 25.3 & 2.16 & - & - & Volcán de Colima (LAH4) \\
\hline Andesite & 24.1 & 2.11 & - & - & Volcán de Colima (LAH4) \\
\hline Andesite & 23.9 & 2.04 & - & - & Volcán de Colima (LAH4) \\
\hline Andesite & 24.5 & 2.23 & - & - & Volcán de Colima (LAH4) \\
\hline Andesite & 26.5 & 2.42 & - & - & Volcán de Colima (LAH4) \\
\hline Andesite & 24.5 & 2.47 & - & - & Volcán de Colima (LAH4) \\
\hline Andesite & 26.3 & 2.34 & - & - & Volcán de Colima (LAH4) \\
\hline Andesite & 24.9 & 2.44 & - & - & Volcán de Colima (LAH4) \\
\hline Andesite & 24.6 & 2.28 & - & - & Volcán de Colima (LAH4) \\
\hline Basaltic andesite & 24.9 & 3.02 & 1.46 & 2.06 & Gunung Merapi (10_18) \\
\hline Basaltic andesite & 17.9 & 2.72 & 1.59 & 1.71 & Gunung Merapi (10_15) \\
\hline Basaltic andesite & 17.1 & 3.13 & 1.46 & 2.14 & Gunung Merapi (10_14) \\
\hline Basaltic andesite & 21.2 & 2.76 & 1.57 & 1.75 & Gunung Merapi (10_16) \\
\hline Basaltic andesite & 13 & 2.55 & 1.59 & 1.61 & Gunung Merapi (10_12) \\
\hline Basaltic andesite & 15.8 & 2.51 & 1.47 & 1.71 & Gunung Merapi (10_13) \\
\hline Basaltic andesite & 11.8 & 2.09 & 1.25 & 1.68 & Gunung Merapi (10_9) \\
\hline Basaltic andesite & 12.1 & 3.44 & 2.12 & 1.62 & Gunung Merapi (10_10) \\
\hline Basaltic andesite & 10.5 & 3.32 & 2.01 & 1.65 & Gunung Merapi (10_8) \\
\hline Basaltic andesite & 12.9 & 3.29 & 1.67 & 1.96 & Gunung Merapi (94_1) \\
\hline Basaltic andesite & 30.8 & 2.7 & 1.12 & 2.4 & Gunung Merapi (10_21) \\
\hline Basaltic andesite & 28 & 2.63 & 1.3 & 2.03 & Gunung Merapi (10_20) \\
\hline Basaltic andesite & 26.1 & 1.94 & 1.08 & 1.79 & Gunung Merapi (10_19) \\
\hline Basaltic andesite & 22.8 & 2.97 & 1.36 & 2.19 & Gunung Merapi (10_17) \\
\hline Basaltic andesite & 17.3 & 1.86 & 0.88 & 2.11 & Gunung Merapi (92_1) \\
\hline Basaltic andesite & 10.5 & 3.57 & 1.65 & 2.17 & Gunung Merapi (01_2) \\
\hline Basaltic andesite & 11.4 & 1.49 & 0.98 & 1.53 & Gunung Merapi (10_24) \\
\hline Basaltic andesite & 10.8 & 2.16 & 0.99 & 2.18 & Gunung Merapi (10_23) \\
\hline Basaltic andesite & 7.4 & 2.56 & 1.42 & 1.8 & Gunung Merapi (10_22) \\
\hline Basaltic andesite & 13.5 & 2.31 & 1.15 & 2.02 & Gunung Merapi (10_26) \\
\hline Basaltic andesite & 12.1 & 2.37 & 1.14 & 2.08 & Gunung Merapi (10_25) \\
\hline Basaltic andesite & 10.7 & 2.25 & 1.33 & 1.69 & Gunung Merapi (13_2) \\
\hline Basaltic andesite & 13.9 & 1.95 & 1.27 & 1.53 & Gunung Merapi (13_3) \\
\hline Basaltic andesite & 20.3 & 2.07 & 0.96 & 2.15 & Gunung Merapi (10_27) \\
\hline Basaltic andesite & 22.8 & 1.28 & 0.82 & 1.56 & Gunung Merapi (13_1) \\
\hline
\end{tabular}

Table 2. Velocity measurements for andesites from Volcán de Colima (Mexico) and andesites and basalticandesites from Merapi (Indonesia) performed for this study. Measurements were made on dry samples at ambient pressure and temperature (see text for details). We also provide the connected porosity of each sample. 


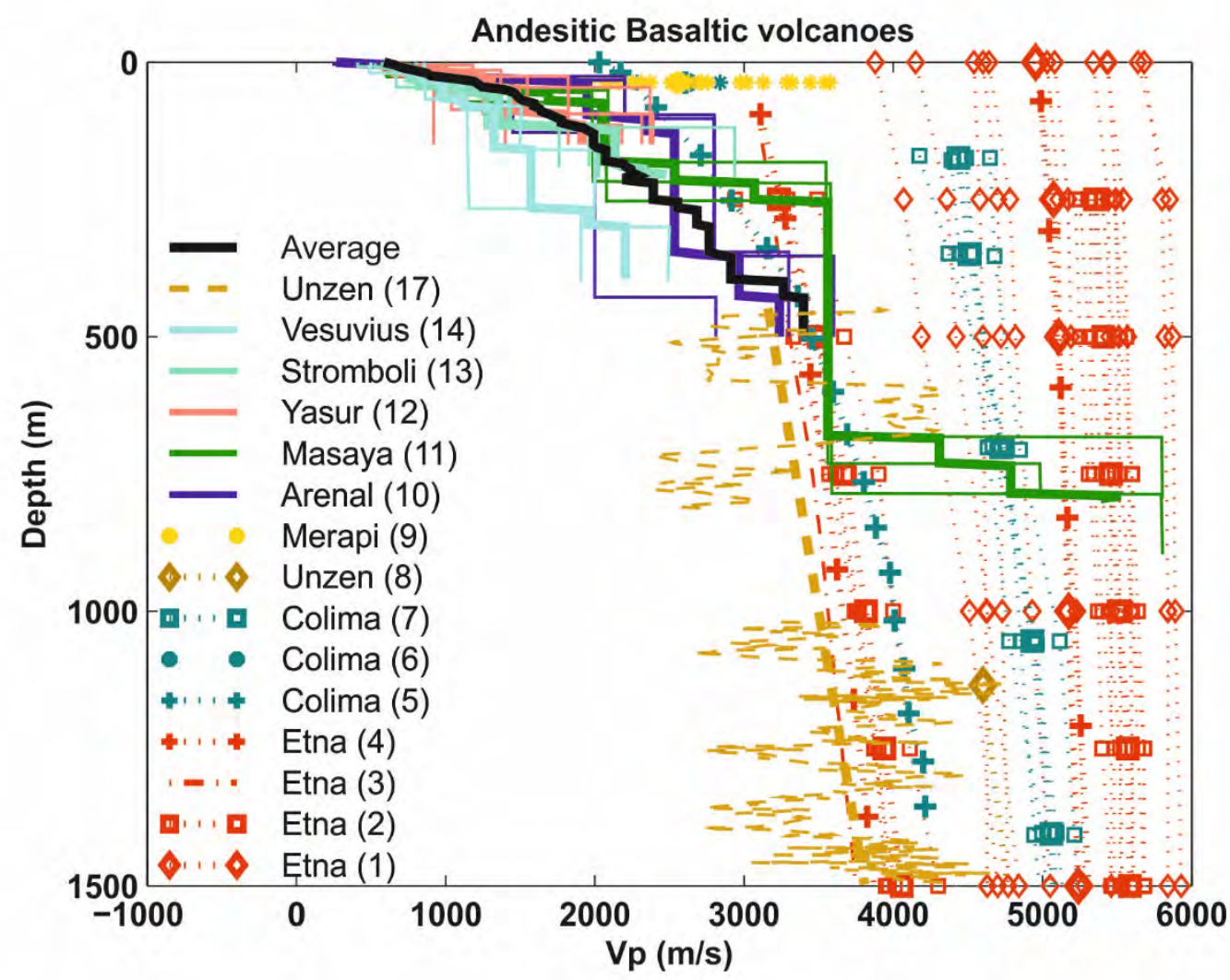

Figure 1a

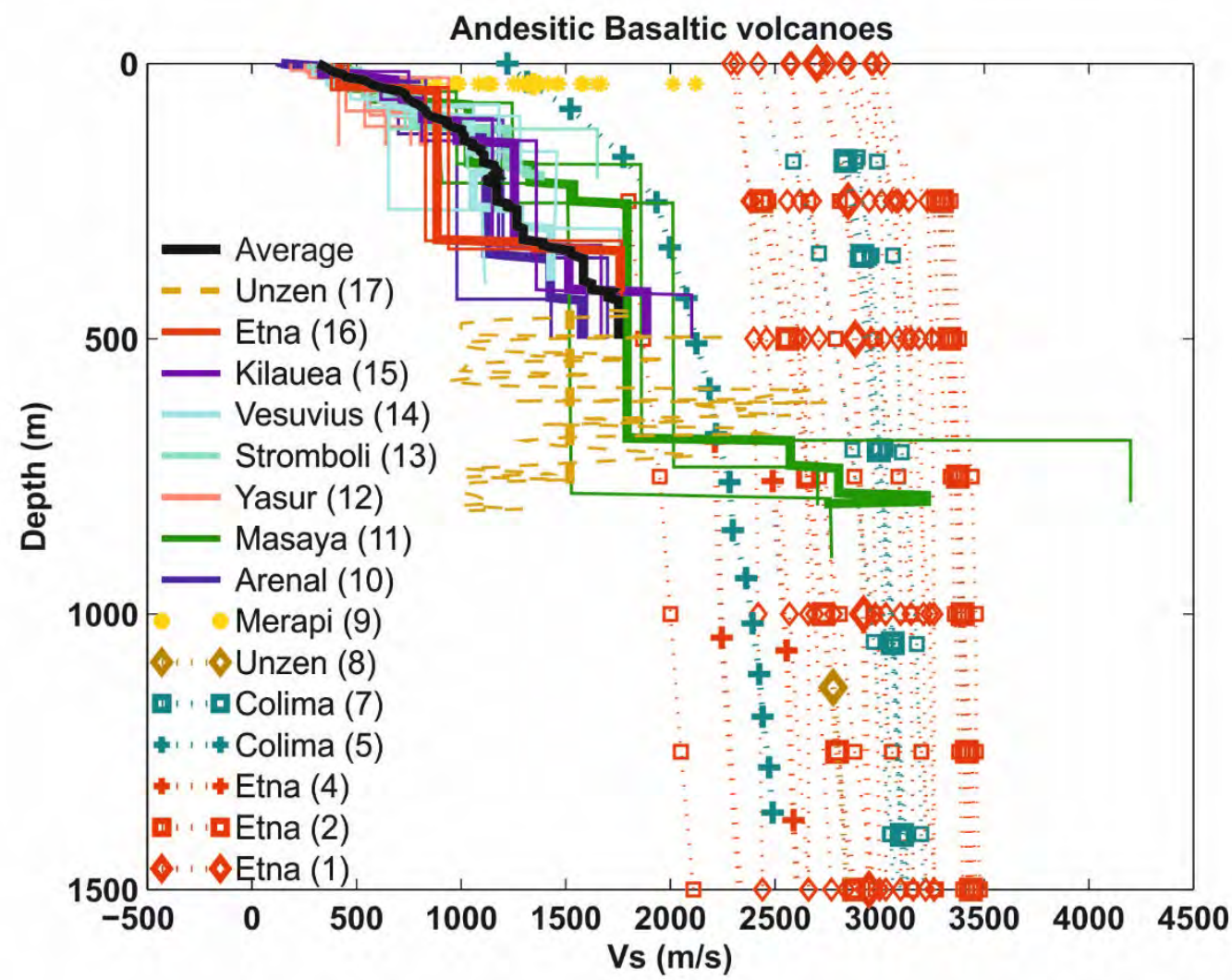

Figure 1b 


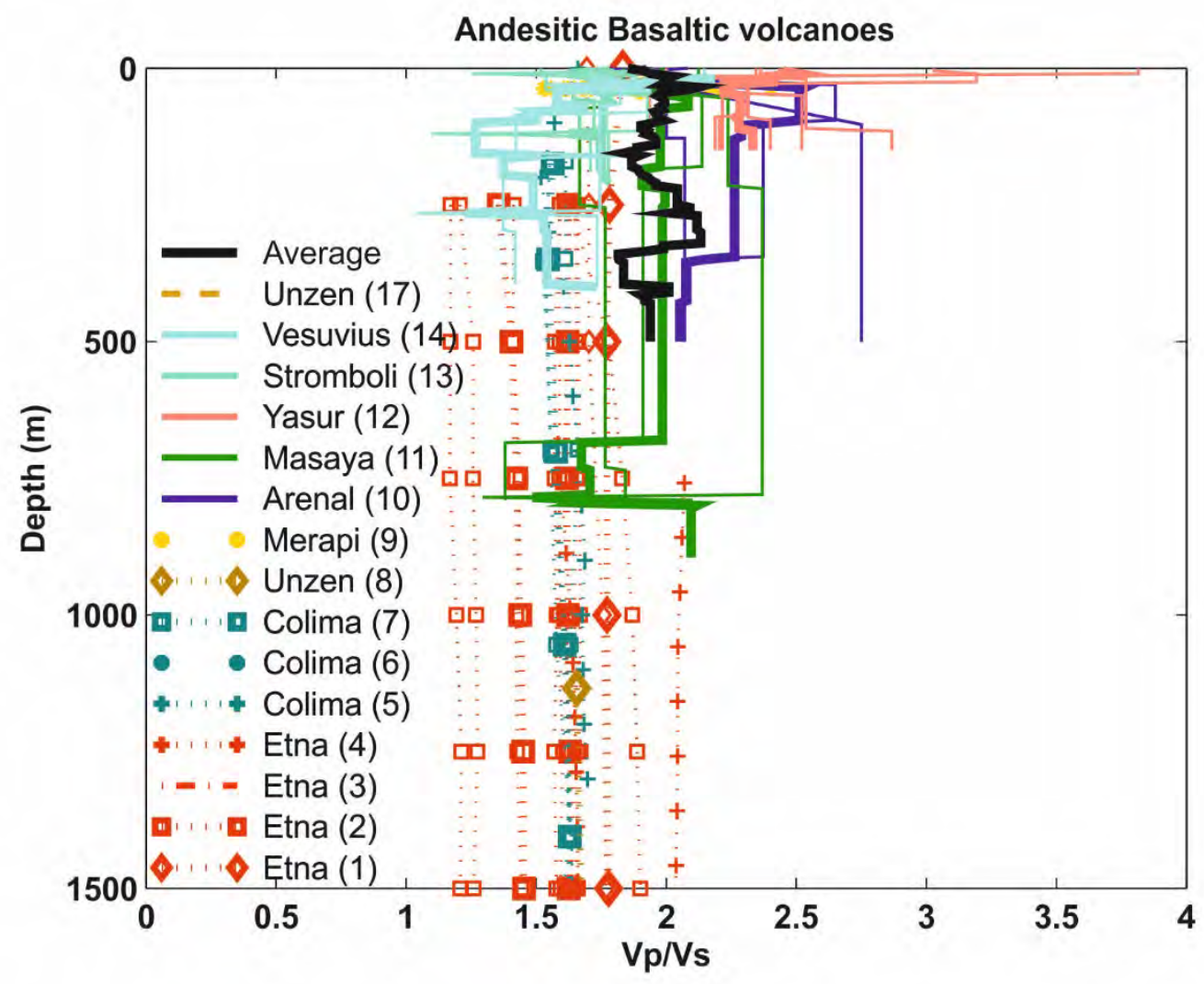

Figure 1c

Figure 1. Individual velocity models (thin lines), laboratory measurements (symbols and dotted lines) and well-logs (dashed lines) obtained for andesitic and basaltic volcanoes. Averaged seismic models (thick lines) and average of the averaged models (thick black line). a) $V_{P}$, b) $\left.V_{S}, c\right) V_{P} / V_{S}$. Numbers in labels indicate references (1: Vanorio et al., 2002; 2: Vinciguerra et al., 2005; 3: Stanchits et al., 2006; 4: Fortin et al;, 2011 ; 5 : Heap et al., $2014 a$; 6 : this study ; 7: Kolzenburg et al., 2012; 8: Scheu et al., 2006; 9: this study; 10: Mora et al., 2006; 11: Métaxian et al., 1997; 12: Perrier et al., 2012 ; 13 : Chouet et al., 1998 ; La Rocca et al., 2000 ; 14 : De Luca et al., 1997 ; 15 : Saccorotti et al., 2003 ; 16 : Saccorotti et al., 2004 ; 17 : Ikeda et al., 2008). 


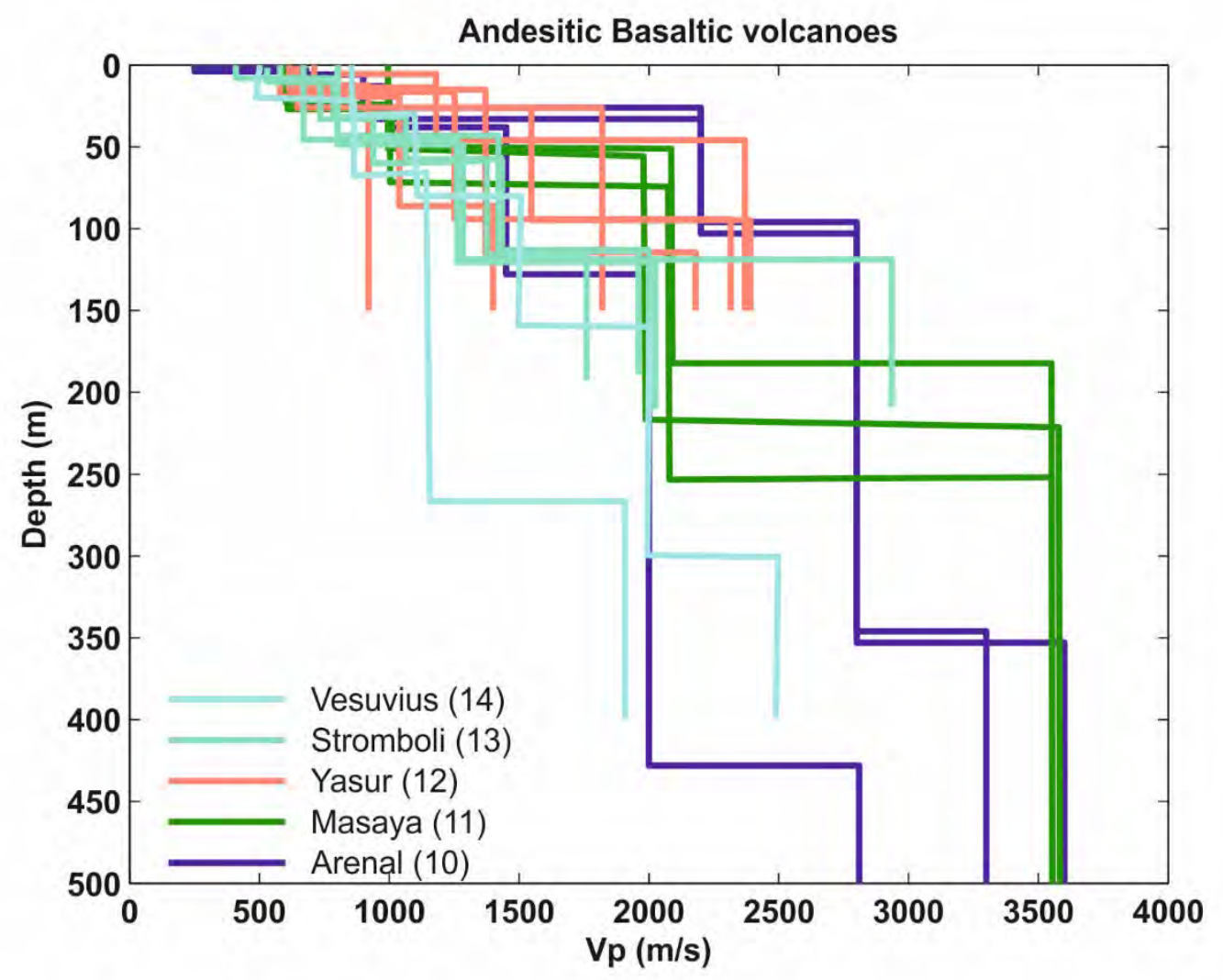

Figure 2a

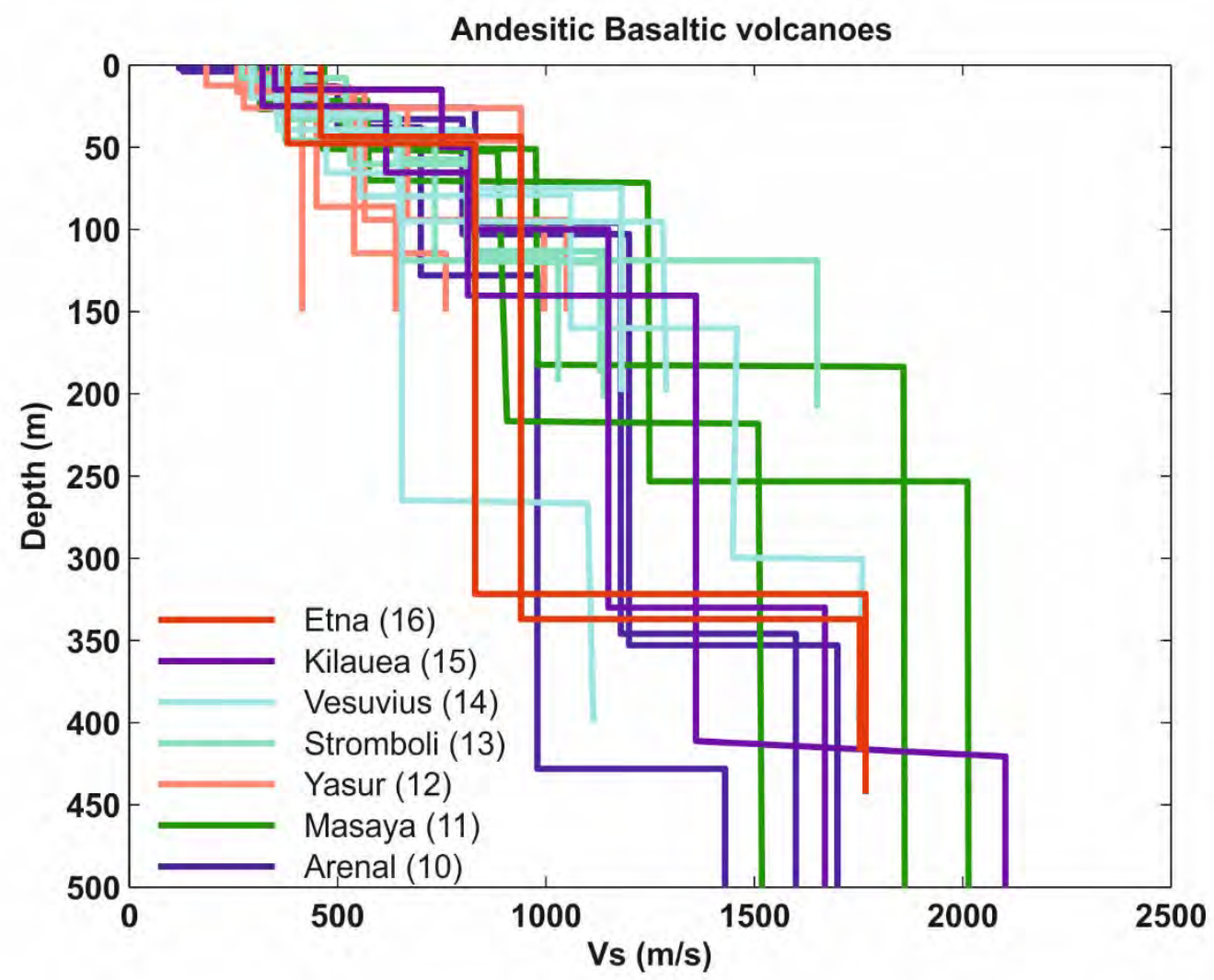

Figure $2 b$

Figure 2. Individual seismic velocity models obtained for andesitic and basaltic volcanoes for the first $500 \mathrm{~m}$ of depth.

a) $\left.V_{p}, b\right) V_{s}$. Numbers in labels indicate references (see caption of Figure 1 ). 


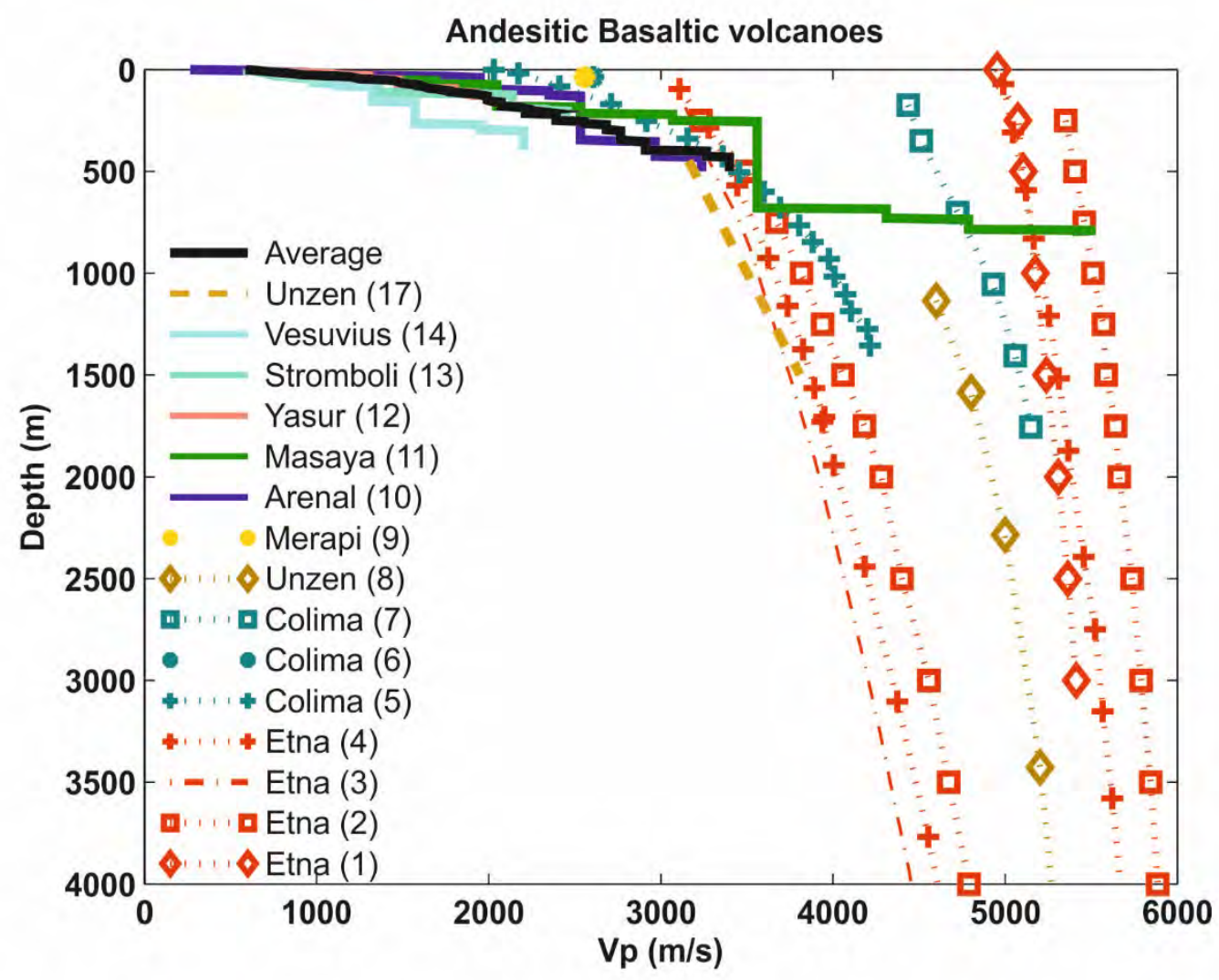

Figure 3a

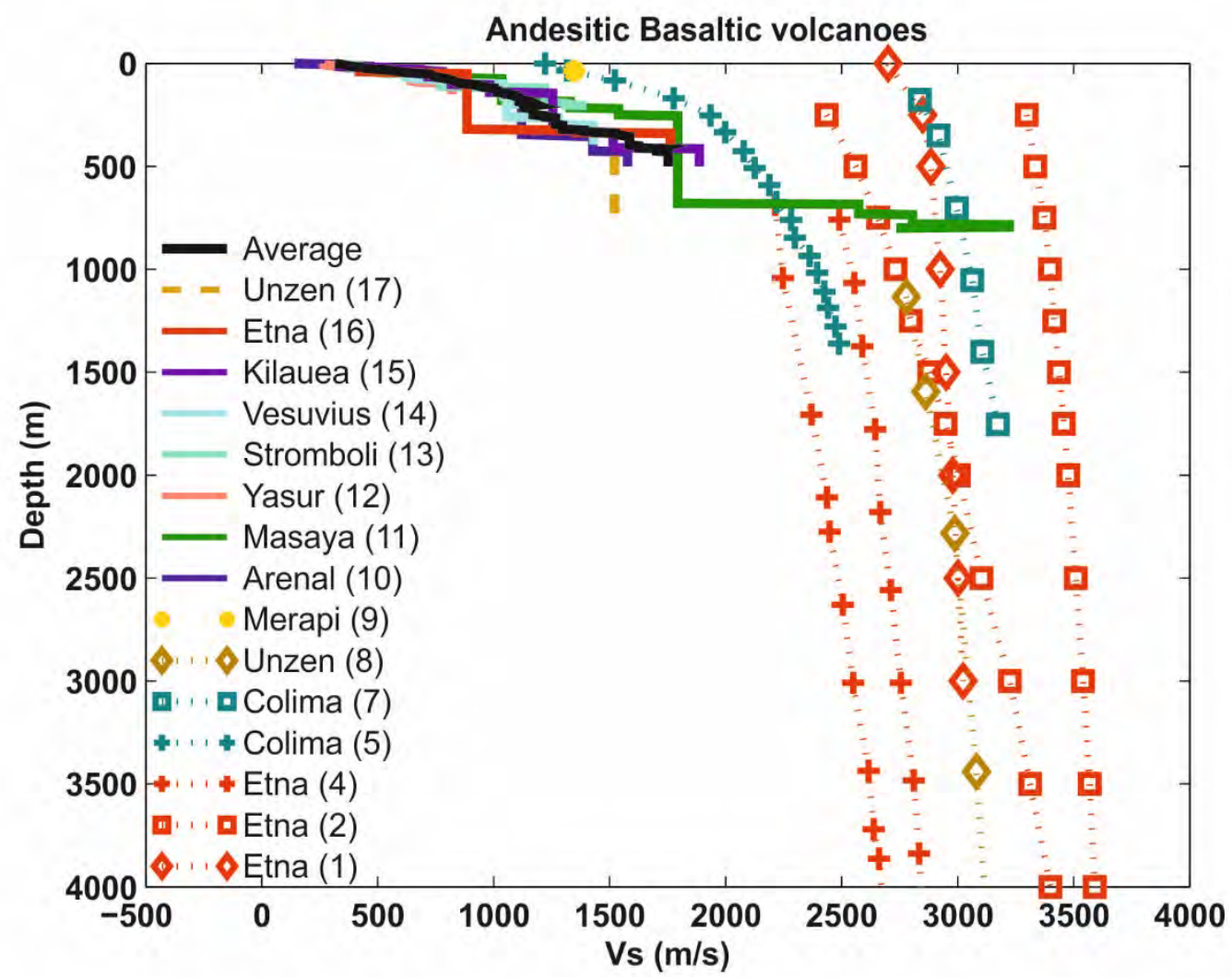

Figure $3 b$ 
Andesitic Basaltic volcanoes

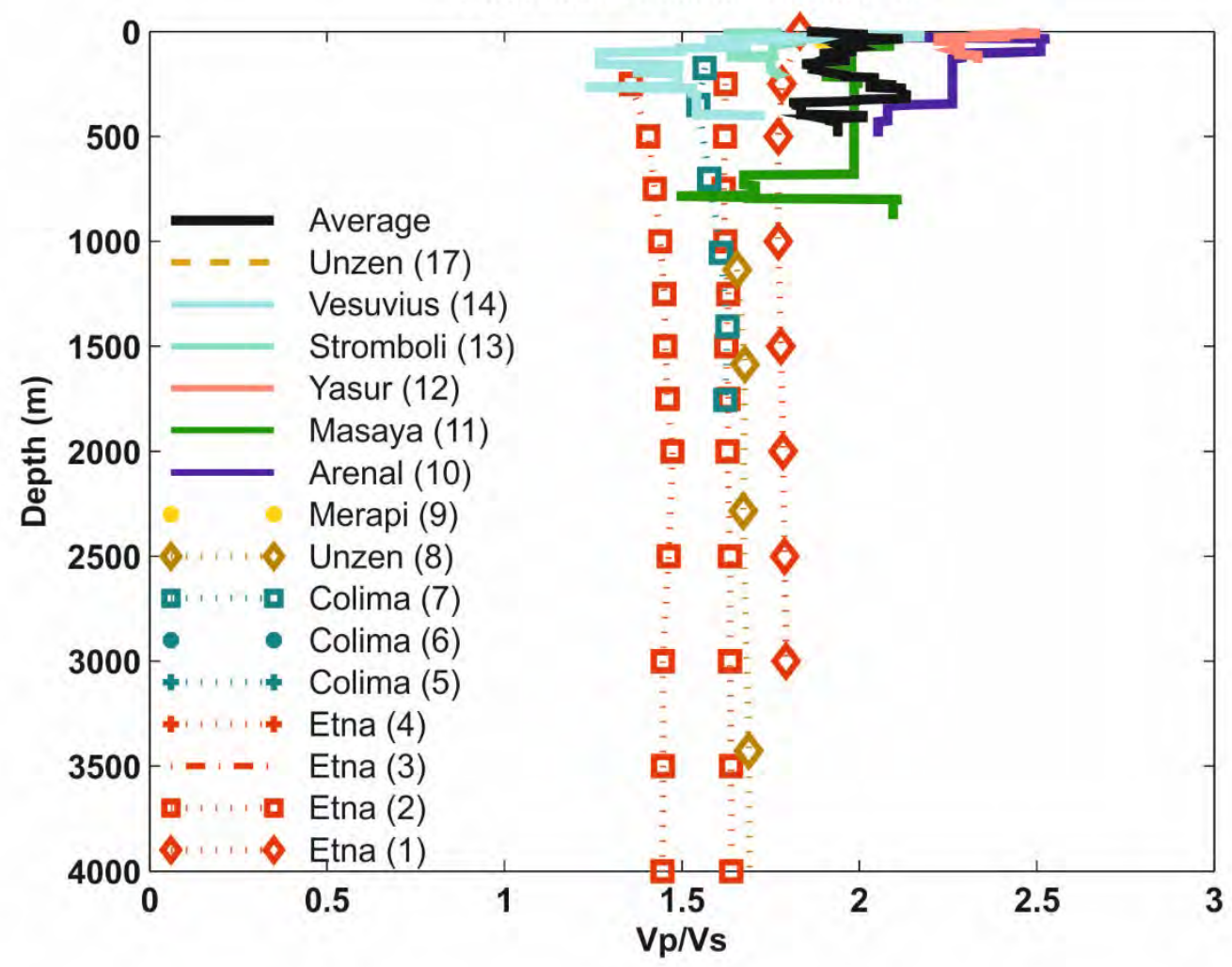

Figure 3c

Figure 3. Same as Figure 1, but for depths up to $4000 \mathrm{~m}$. Only averages of seismic models, laboratory measurements and seismic logs are plotted for andesitic and basaltic volcanoes. a) $\left.\left.V_{p}, b\right) V_{S}, c\right) V_{P} / V_{S}$.

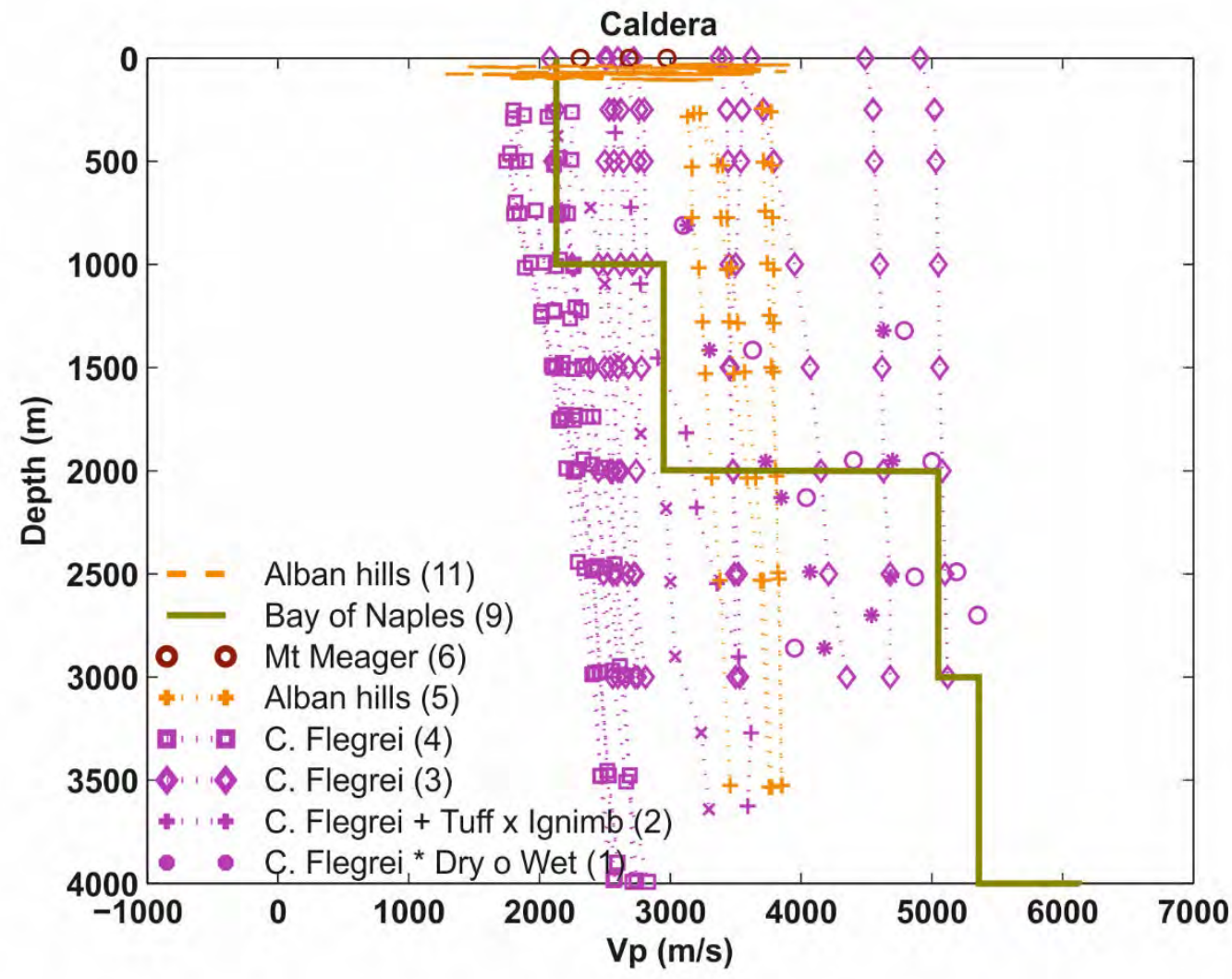

Figure 4a 


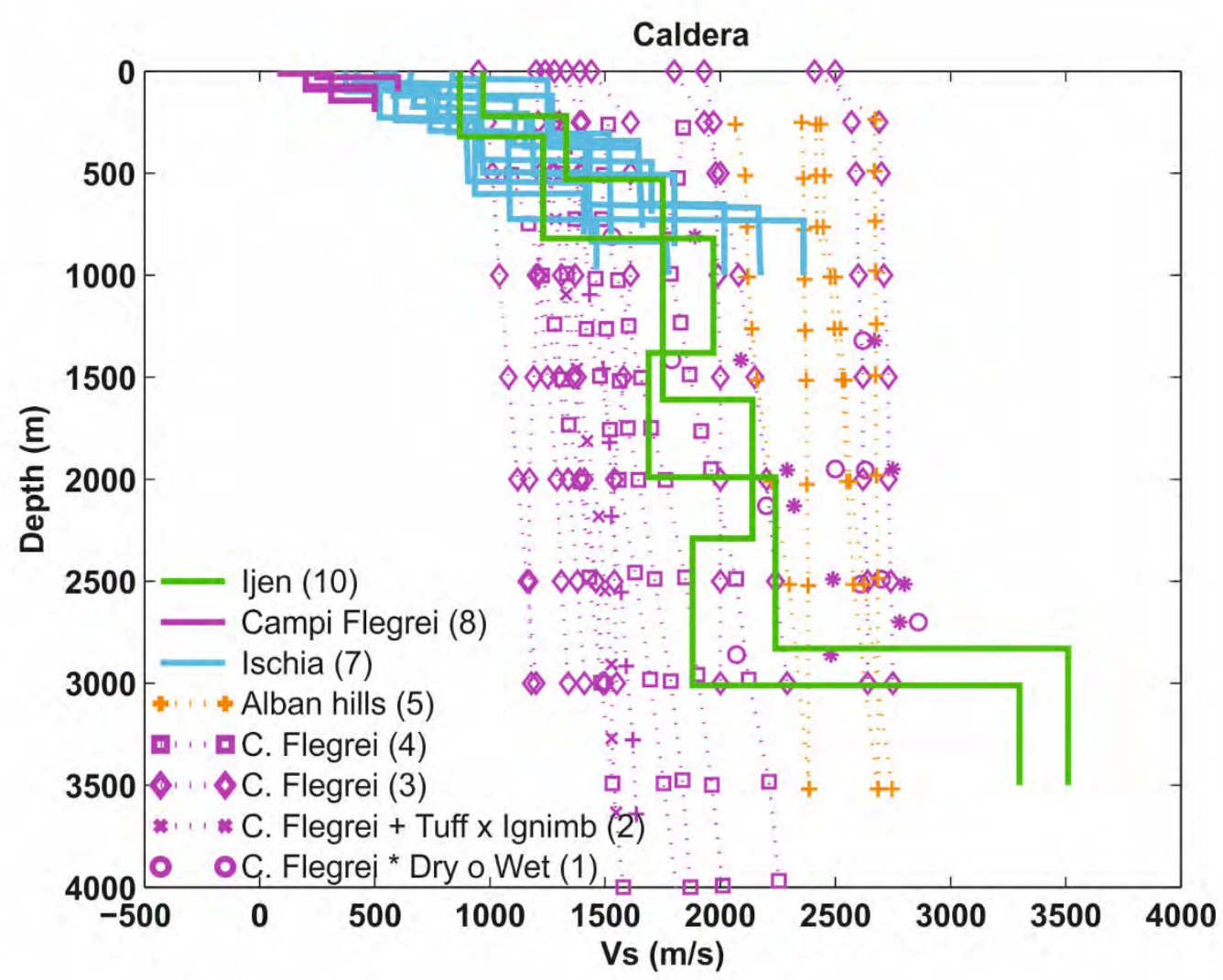

Figure 4b

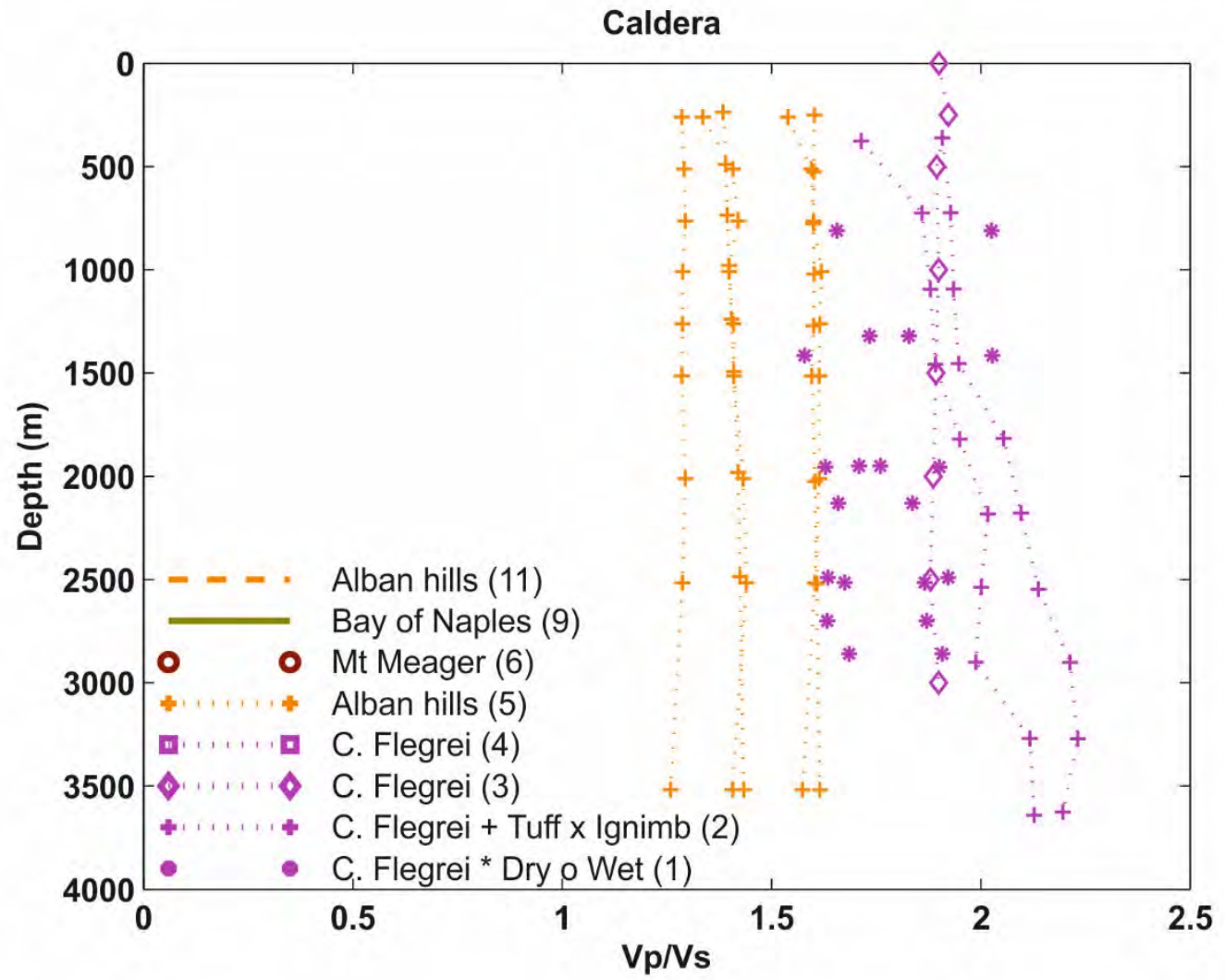

Figure 4c

Figure 4. Velocity models (thin lines), laboratory measurements (symbols and dotted lines) and well-logs (dashed lines) obtained for calderas. a) $\left.\left.V_{p}, b\right) V_{S}, c\right) V_{p} / V_{s}$. Numbers in labels indicate references (1: Zamora et al., 1994; 2: Heap et al., 2014b; 3: Vanorio et al., 2002; 4: Vinciguerra et al., 2006; 5: Vinciguerra et al., 2009; 6: Heap et al., 2015a; 7: Strollo et al., 2015; 8: Tramelli et al., 2010; 9: Judenherc and Zollo, 2004; 10: Spica et al., 2015; 11: Vinciguerra et al., 2009). 


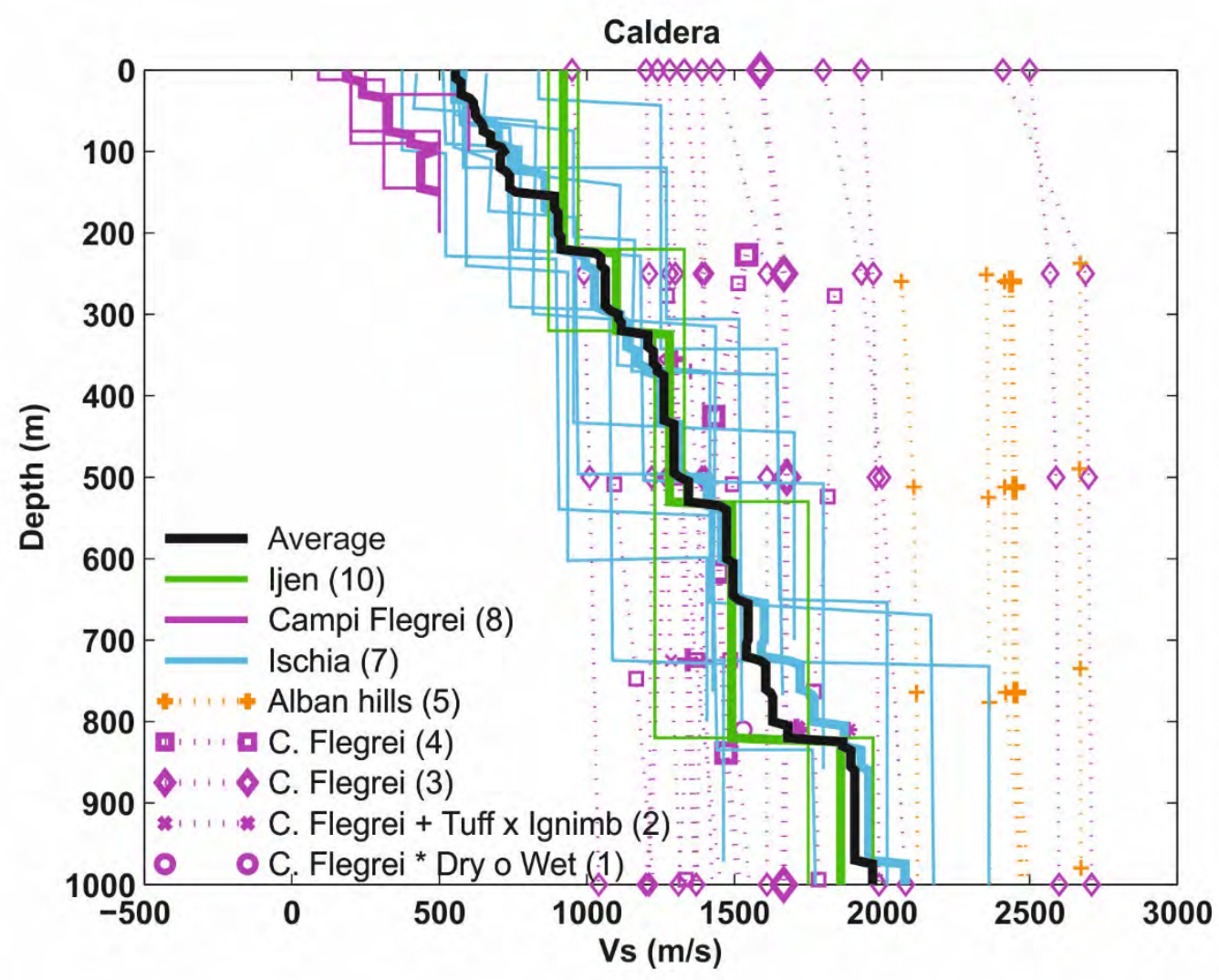

Figure 5. Same as Figure 4 for the first $1000 \mathrm{~m}$ of depth. Averaged seismic models (thick lines) and average of the averaged models (thick black line). 

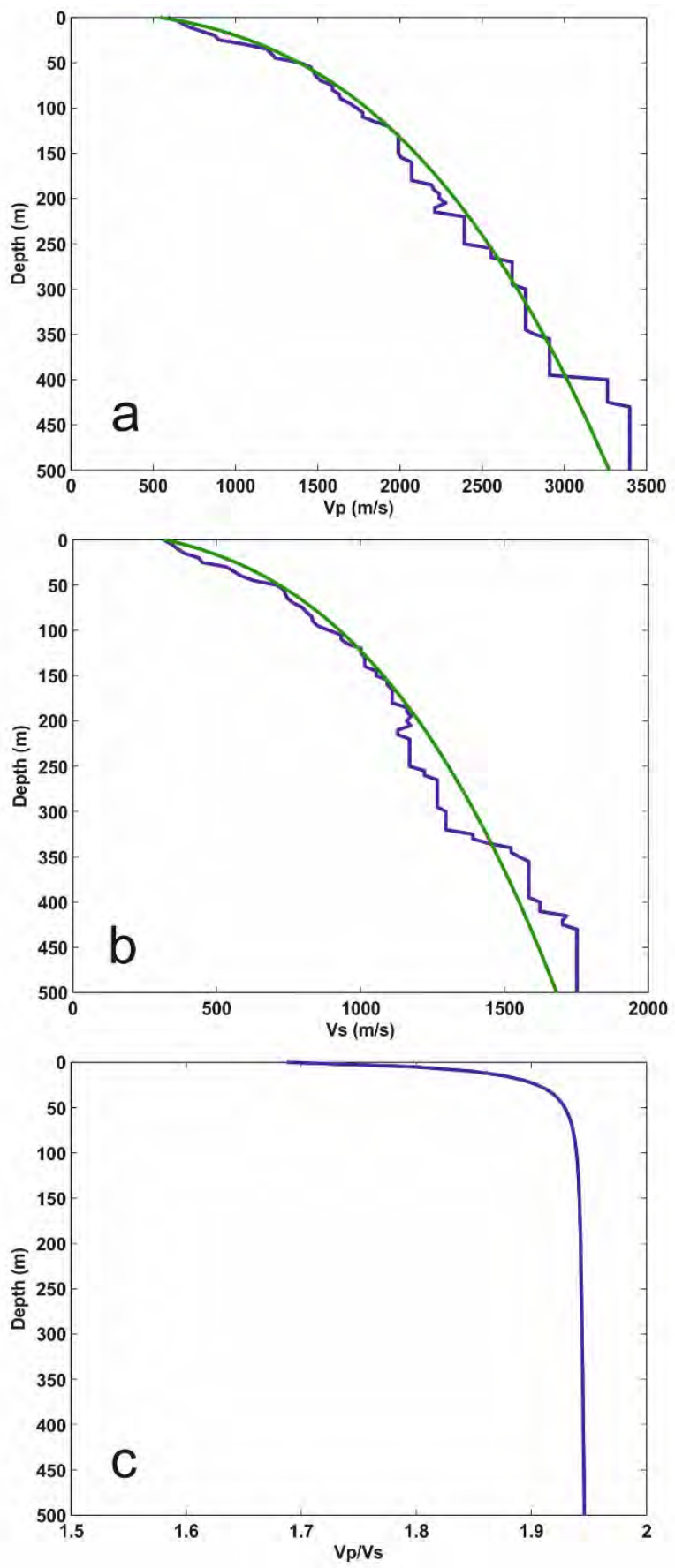

Figure 6. Generic analytical model (green lines) and average model (blue lines). a) $\left.\left.V_{P} ; b\right) V_{S}, c\right) V_{P} / V_{S}$ for the analytical model. 